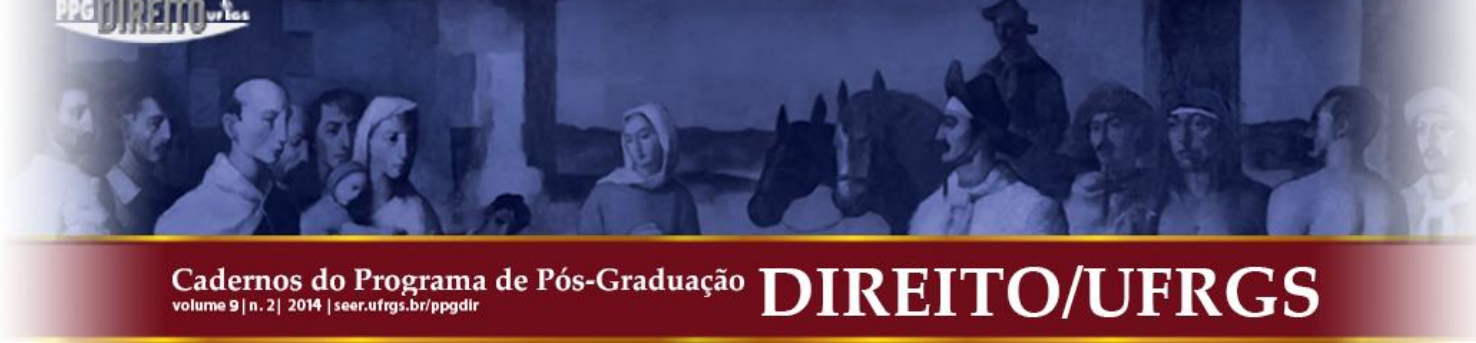

\title{
APONTAMENTOS SOBRE A EFETIVIDADE DA TUTELA JURISDICIONAL EM MATÉRIA PREVIDENCIÁRIA
}

\author{
NOTES ON THE EFFECTIVENESS OF JURISDICTIONAL PROTECTION IN SOCIAL \\ SECURITY MATTERS
} \begin{abstract}
previdenciários consistem em substancial parcela das demandas judiciais em curso no país. A despeito da sua importância em termos quantitativos, porém, ainda é tímido o interesse da doutrina no direito previdenciário em seu aspecto processual. O presente trabalho tem por objetivo analisar a tutela jurisdicional em matéria previdenciária enquanto instrumento hábil a equacionar os relevantes valores constitucionais em discussão. Vale-se, para tanto, da noção de lide previdenciária, na qual residiria o traço distintivo do processo judicial previdenciário. Em um primeiro momento, objetiva-se delinear a demanda judicial previdenciária, discorrendo sobre seu caráter individual e multifatorial, com destaque para a influência da Administração Pública e do Poder Judiciário no incremento da litigiosidade nessa seara. Em um segundo momento, analisa-se o processo judicial previdenciário, destacando os pontos críticos que impedem seja ele um processo de resultados, a saber, o distanciamento entre as esferas administrativa e judicial, a inadequação do procedimento comum, o excesso de instrução probatória e a postura pouco colaborativa das partes. Pretende-se, enfim, perquirir sobre a conveniência de se falar em um direito processual previdenciário e sobre as possibilidades que se abrem, a partir daí, para que esse processo judicial atinja seus escopos.
\end{abstract}

PALAVRAS-CHAVE: Direito Previdenciário; Benefícios
Previdenciários; Processo Judicial Previdenciário; Instrumentalidade;

PALAVRAS-CHAVE: Direito Previdenciário; Benefícios
Previdenciários; Processo Judicial Previdenciário; Instrumentalidade; Eficiência.

SUMÁRIO: Introdução. 1. Contornos atuais da demanda judicial previdenciária. 1.1. Uma demanda individual de causa multifatorial. 1.2. Dois fatores fundamentais para o crescimento da demanda previdenciária. 1.3. A configuração da lide previdenciária. 2. A tutela jurisdicional previdenciária. 2.1. Aproximação das esferas administrativa e judicial e correta delimitação da lide. 2.2. Inadequação de procedimentos e excesso de instrução probatória. 2.3. Um direito processual previdenciário? Considerações finais. Referências.

ABSTRACT: Lawsuits in which the concession of social security benefits is pursued comprise a substantial portion of lawsuits ongoing in the country. Despite its importance in quantitative terms, however, doctrine has still little interest in social security law in its procedural aspect. The present work has the purpose to analyze the jurisdictional protection in social security benefits matters as an apt instrument to equate the relevant constitutional values in discussion. It assumes, therefore, the concept of social security case, in which resides the distinctive feature of the welfare judicial proceedings. At first, the objective is to delineate the social security litigation, discussing its individual and multifactorial character, emphasizing the influence of public administration and the judiciary in the increase of litigation in this area. In a second moment, we analyze the social security judicial proceedings, highlighting the critical issues that prevent it to be a process of results, namely the distance between administrative and judicial realms, the inadequacy of the common procedures, excess of discovery phases, and little collaborative parties. We intend, ultimately, to assert the convenience of talking about a specific social security procedural law and the possibilities that are open, thenceforth, in order that these judicial proceedings reach its purposes.

KEYWORDS: Social Security Law; Social Security Benefits; Social Security Legal Proceedings; Instrumentality; Efficiency.

\section{INTRODUÇÃO}

Passados vinte e cinco anos do advento da Constituição da República, questiona-se com veemência a capacidade de o Poder Judiciário, da forma até então estruturada, absorver com eficiência o crescente número de demandas judiciais em curso no país. Se o fenômeno da

\footnotetext{
* Especialista em Direito Previdenciário pela Pontifícia Universidade Católica de Minas Gerais (PUC-MG), em Direito Público pela Universidade Nacional de Brasília (UnB) e em Direito Ambiental pela Universidade Federal do Rio Grande do Sul (UFRGS). Procuradora Federal no estado do Paraná, Coordenadora do Serviço Previdenciário da Procuradoria Federal no Estado do Paraná.
} 


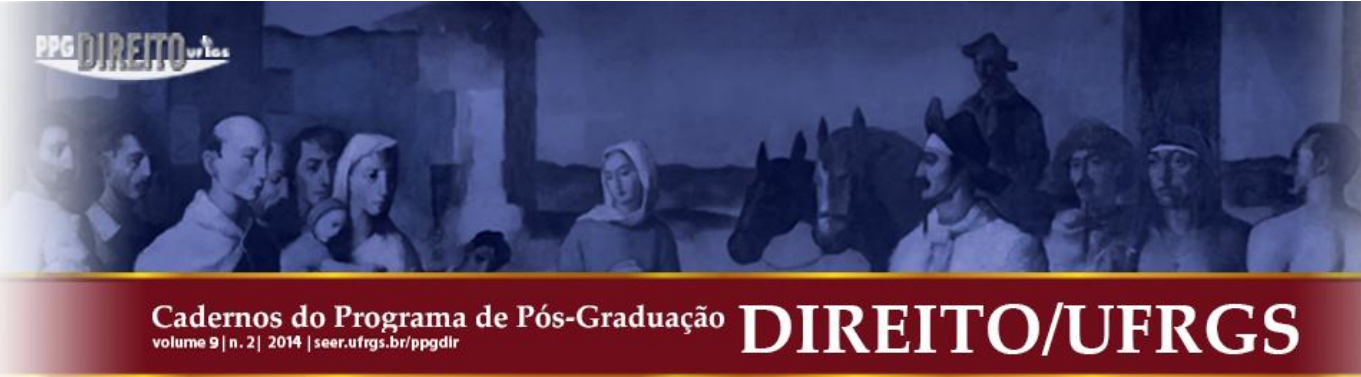

pretende, em síntese, é questionar se o processo previdenciário, em sua configuração atual. permite uma tutela jurisdicional efetiva dos valores constitucionais nele envolvidos.

\section{CONTORNOS ATUAIS DA DEMANDA JUDICIAL PREVIDENCIÁRIA}

\subsection{Uma demanda individual de causa multifatorial}

Ações judiciais que versam sobre benefícios previdenciários se enquadram no espectro maior do pleito a um direito social. Com efeito, a Previdência Social é direito fundamental de segunda geração, previsto no artigo $6^{\circ}$ da Constituição da República, segundo o qual "são direitos sociais a educação, a saúde, o trabalho, a moradia, o lazer, a segurança, a previdência social, a proteção à maternidade e à infância, a assistência aos desamparados, na forma desta Constituição." 3

À vista da necessidade de efetivação desse direito social, a Previdência Social erige-se constitucionalmente como política pública integrante da Seguridade Social, organizada sob a forma de regime geral, de caráter contributivo e filiação obrigatória e cujos contornos gerais vêm delineados no art. 201 da Constituição. Trata-se, pois, de verdadeira política social que objetiva suprir as necessidades daqueles que foram atingidos por alguma contingência social. ${ }^{4}$

O cotejo de ambas as disposições constitucionais permite afirmar que, em matéria previdenciária, está-se diante de um direito social com dupla dimensão. É que, na lição de Canotilho, direitos tais têm, a um só tempo, uma dimensão de direito subjetivo, ou seja, um direito a proteção previdenciária inserido no espaço existencial do cidadão, independentemente da possibilidade de sua exequibilidade imediata, e outra dimensão jurídico-objetiva, por meio da qual há uma imposição constitucional legiferante, a fim de que o legislador atue positivamente, criando as condições para o exercício daqueles direitos ou efetivamente fornecendo prestações aos cidadãos. ${ }^{5}$

\footnotetext{
${ }^{3}$ Antes dela, a Declaração Universal dos Direitos do Homem de 1948 já dispunha que "toda pessoa tem direito à segurança, em caso de desemprego, doença, invalidez, viuvez, velhice ou outros casos de perda dos meios de subsistência em circunstâncias fora de seu controle".

${ }^{4}$ Política social é o complexo de preceitos e programas que visam ao bem-estar e ao desenvolvimento da população, assim como a promoção de suas aspirações de progresso social. Incluída nas políticas públicas, ela se volta à implementação de direitos sociais. TSUTIYA, Augusto Massayuri. Curso de Direito da Seguridade Social. São Paulo: Saraiva, 2007. p. 202-203.

${ }^{5}$ CANOTILHO, José Joaquim Gomes. Constituição Dirigente e Vinculação do Legislador. 2. Ed. Coimbra: Coimbra, 2001. p. 368-369. A relevante questão do reconhecimento de direitos subjetivos originários a
} 


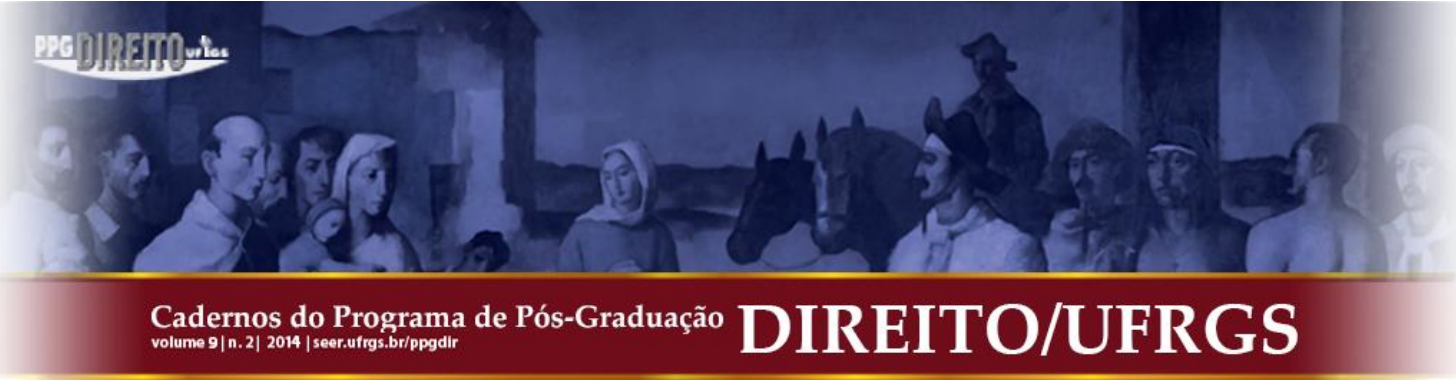

Considerando que mais da metade da população economicamente ativa do país é vinculada ao Regime Geral da Previdência Social, e não a regimes próprios ${ }^{6}$, a concretização do direito constitucional à previdência no Brasil se dá essencialmente por meio da Lei n. ${ }^{\circ}$ 8.212/91, que dispõe sobre a organização da Seguridade Social e institui seu Plano de Custeio, e da Lei n. ${ }^{\circ}$ 8.213/91, que disciplina os Planos de Benefícios do Regime Geral da Previdência Social no Brasil. $^{7}$ Assim, o direito à proteção previdenciária, fundado na Constituição, é exercido, em grande medida, com base na legislação ordinária que prevê os requisitos e disciplina os benefícios e serviços previdenciários devidos a cada cidadão filiado ao Regime Geral, quando acometido de qualquer dos riscos sociais constitucionalmente protegidos.

De fato, e diversamente do que ocorre com outros direitos sociais, a proteção previdenciária do Regime Geral não é, em tese, inexistente ou insuficiente; embora a Constituição confira ao legislador uma margem substancial de autonomia na definição da forma e medida em que esse direito social deva ser assegurado (livre espaço de conformação $^{8}$, fato é que os diversos riscos sociais a serem cobertos pelo sistema vêm expressamente elencados no texto constitucional, que estendeu à população rural, ademais, a mesma proteção previdenciária conferida à população urbana. ${ }^{9}$ Em verdade, como destaca Viana, o Brasil possui a maior cobertura previdenciária da América Latina. ${ }^{10}$

prestações sociais e os limites do Estado social de Direito, conquanto pressuposta para a análise da efetivação do direito social à previdência social, foge ao escopo deste trabalho. Sobre o tema, vide SARLET, Ingo Wolfgang. A eficácia dos direitos fundamentais. 2. ed. Porto Alegre: Livraria do Advogado, 2001, especialmente p. 294296, quanto ao direito à previdência social.

${ }^{6}$ Segundo dados da Pesquisa Nacional por Amostra de Domicílios - PNAD de 2009, 41,97 milhões (49,7\%) de cidadãos estão filiadas ao RGPS, 7,17 milhões (8,5\%) são segurados especiais e 1,10 milhão de pessoas $(1,3 \%)$ são beneficiárias da Previdência Social, sendo que apenas 6,32 milhões (7,5\%) são filiados a regimes próprios de previdência social. Por outro lado, mais de 27,81 milhões de pessoas, o que corresponde a cerca de $33,0 \%$ da população ocupada total, não estão protegidas por qualquer tipo de seguro social. Ministério da Previdência Social. Secretaria de Políticas de Previdência Social. Projeções atuariais para o Regime Geral de Previdência Social. Brasília, março de 2012. Disponível em: <http://www.planejamento.gov.br/secretarias/ upload/Arquivos/sof/orcamento_13/Anexo_IV.5_RGPS.pdf>. Acesso em: 30 dez. 2013.

7 "O direito à previdência social já foi objeto de concretização e detalhada regulamentação na esfera infraconstitucional.” SARLET, Ingo Wolfgang. A eficácia dos direitos fundamentais. 2. ed. Porto Alegre: Livraria do Advogado, 2001. p. 294.

${ }^{8}$ KRELL, Andreas J. Controle judicial dos serviços públicos básicos na base dos direitos fundamentais sociais. In: SARLET, Ingo Wolfgang (Org.). A Constituição concretizada: construindo pontes com o público e o privado. Porto Alegre: Livraria do Advogado, 2000. p. 29.

9 O art. 194, parágrafo único, I, da Constituição da República, prevê como objetivo da seguridade social a universalidade da cobertura e do atendimento e a uniformidade e equivalência dos benefícios e serviços às populações urbanas e rurais. Por sua vez, os incisos do art. 201 determinam a cobertura dos eventos de doença, invalidez, morte e idade avançada, além de proteção à maternidade, especialmente à gestante, proteção ao 


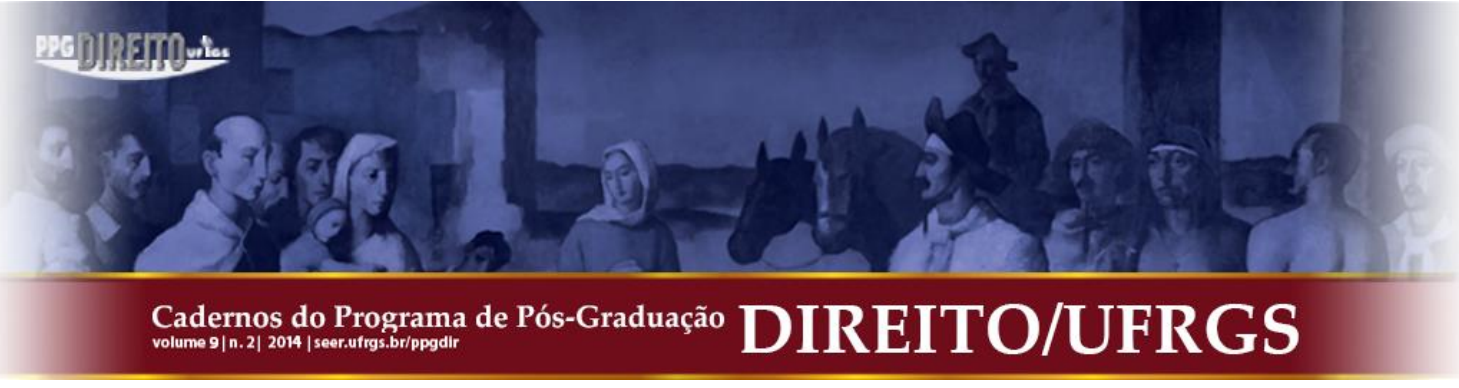

pacificador desse conflito e, ainda, como produtor normativo de todo o contexto de direito positivo envolvido na sua solução. ${ }^{12}$

Ocorre que, em matéria previdenciária, diversos fatores externos e internos impulsionam a conflitualidade. Por trás da aparente singeleza dessa específica lide pública, que individualmente derivaria tão-só da contraposição entre cidadão e Administração diante de uma pretensão de prestação positiva por parte do Estado, inúmeras variantes atuam para que a política social previdenciária seja a maior causa de litígio no Brasil ${ }^{13}$.

Em recente estudo da Fundação Getúlio Vargas para o Conselho Nacional de Justiça, alguns fatores foram elencados hipoteticamente como ensejadores de potenciais conflitos na seara previdenciária, dentre os quais sobressai, no que toca a este trabalho, a regulamentação legislativa instável e pouco clara, a atuação estatal administrativa, formalista e ineficiente, que conduziria a população a buscar a tutela previdenciária pela via judicial, e também a atuação do Poder Judiciário, lento, instável e pouco uniforme. Ao procurar traçar o perfil das demandas em matéria previdenciária, referido estudo chegou a conclusão que bem resume a complexidade da matéria:

\begin{abstract}
Os conflitos envolvendo direito previdenciário evidenciam a dinâmica dos fatores externos e internos que impulsionam a litigiosidade. Os principais atores do sistema político e jurídico interagem nestes conflitos: os cidadãos como beneficiários e demandantes judiciais; o Estado como legislador, regulador, gestor do sistema previdenciário e julgador administrativo e judicial dos conflitos que lhe são submetidos; o mercado e o empresariado como financiadores, ao lado do Estado e do sistema previdenciário, e desencadeadores da maior ou menor procura pelos respectivos benefícios; a comunidade científica no subsídio das teses jurídicas e de hermenêutica legislativa que fundamentam demandas judiciais; os advogados e a mídia como polos de disseminação de informação e de catálise de litígios, entre outros atores eventualmente envolvidos.

Além disso, o regime jurídico previdenciário articula um delicado confronto político entre a promoção de justiça social e o equilíbrio econômico. Os conflitos previdenciários refletem complexas características da sociedade contemporânea: explosão demográfica, longevidade da população, sociedade de massa e de consumo etc. ${ }^{14}$
\end{abstract}

\footnotetext{
${ }^{12}$ BUENO, Cassio Scarpinella. A emergência do direito processual público. In: SUNDFELD, Carlos Ari e BUENO, Cassio Scarpinella (Org.). Direito processual público: a Fazenda Pública em Juízo. São Paulo: Malheiros, 2000. p. 35.

13 BRASIL. Conselho Nacional de Justiça. 100 maiores litigantes. Brasília, 2012. Disponível em: $\langle$ http://www.cnj.jus.br/images/pesquisas-judiciarias/Publicacoes/100_ maiores_litigantes.pdf $>$. Acesso em: 02 set. 2013.

${ }^{14}$ BRASIL. Conselho Nacional de Justiça. Fundação Getúlio Vargas. Diagnóstico sobre as causas de aumento das demandas judiciais cíveis, mapeamento das demandas repetitivas e propositura de soluções préprocessuais, processuais e gerenciais à morosidade da Justiça. Disponível em: $<$ http://www.cnj.jus.br/images/pesquisas-judiciarias/Publicacoes/relat_pesquisa_fgv_edital1_2009.pdf>. Acesso em: 13 set. 2013.
} 


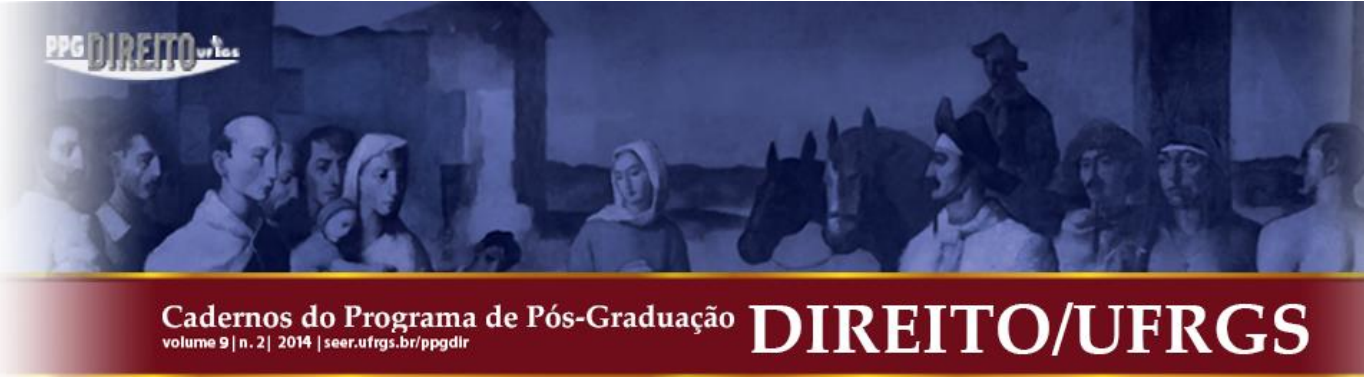

Em matéria previdenciária, portanto, a noção de lide pública, conquanto indispensável para o direito processual, perde seus contornos ante a interação de diversos fatores e, em especial, em razão da contraposição, em nível extraprocessual, de dois atores processuais: de um lado, uma Administração ainda deficiente no reconhecimento e efetivação de direitos previdenciários; de outro, um Poder Judiciário que assumiu uma função essencialmente protetiva no trato da matéria.

\subsection{Dois fatores fundamentais para o crescimento da demanda previdenciária}

Não é nova a crítica doutrinária ao empenho dos poderes públicos em implementar as políticas relativas aos direitos fundamentais. Especificamente em matéria previdenciária, pode-se observar que uma eficácia social reduzida dos direitos fundamentais sociais não se deve à falta de leis ordinárias, e sim à não-prestação - ou à má-prestação - do serviço pelo Poder Público. ${ }^{15}$

O paradigma da Administração Pública brasileira, conquanto se insira no tipo ideal conformado pelo Estado Democrático de Direito, sofreu influxos voltados para a eficiência somente a partir da reforma gerencial promovida pela Emenda Constitucional n. ${ }^{\circ}$ 19/98. Até há pouco mais de uma década, a autarquia previdenciária, como de resto a Administração Pública em geral, ainda não tinha bem definidos os contornos da procedimentalização de seus atos e a necessidade de fundamentação adequada de suas decisões. A despeito da previsão constitucional das garantias do cidadão em qualquer processo, a regulamentação do processo administrativo no âmbito da Administração Pública Federal somente se deu com o advento da Lei n. ${ }^{\circ}$ 9.784/99. Na esfera previdenciária, outrossim, a imperativa observância de uma sequência de atos bem definida, por meio da qual se garanta a participação ativa do cidadão na formação da decisão, somente foi regulamentada internamente pela Instrução Normativa n. ${ }^{\circ}$ 45/2010, que hoje disciplina o processo administrativo previdenciário no âmbito do Instituto Nacional do Seguro Social.

\footnotetext{
${ }^{15}$ KRELL, Andreas J. Controle judicial dos serviços públicos básicos na base dos direitos fundamentais sociais. In: SARLET, Ingo Wolfgang (Org.). A Constituição concretizada: construindo pontes com o público e o privado. Porto Alegre: Livraria do Advogado, 2000. p. 32.
} 


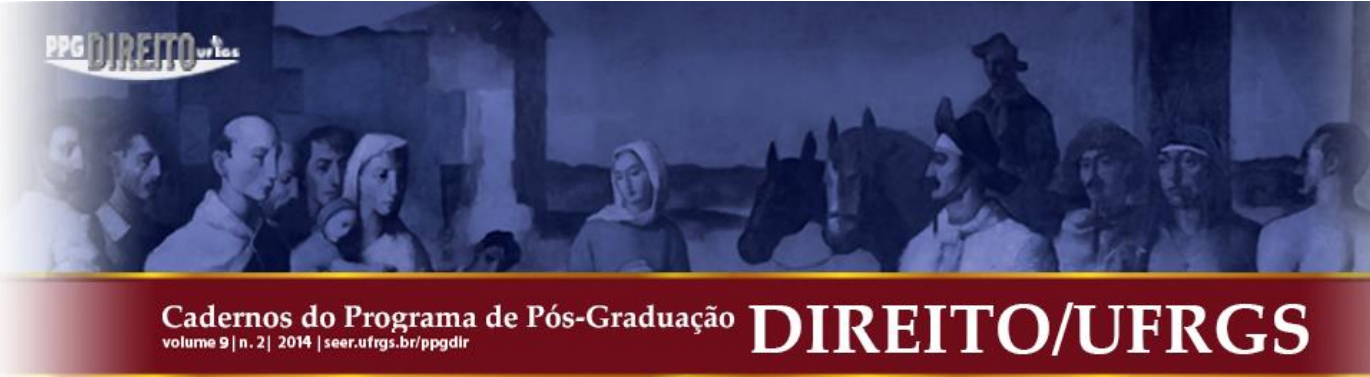

Atualmente, pois, Constituição e legislação ordinária preveem diversos meios de inclusão dos administrados no âmbito da esfera decisória da Administração, filiando-se à moderna tendência de processualização da atividade administrativa ${ }^{16}$. Além disso, um grande esforço tem sido feito no sentido de conferir transparência aos atos administrativos e garantir o contraditório no âmbito dos processos respectivos. Todavia, se hoje o Instituto Nacional do Seguro Social possui um dos mais sofisticados sistemas de acompanhamento de gestão do serviço público federal e vem realizando real esforço de capacitação de seus servidores e ampliação de seu atendimento, as inovações gerenciais são recentes; da mesma forma, os instrumentos de aproximação do Instituto com a sociedade civil para cumprimento do seu papel de conscientização e esclarecimento da população, embora existentes, ainda são incipientes.

Às deficiências da autarquia previdenciária no reconhecimento de direitos se soma uma disseminada desconfiança quanto à lisura dos atos administrativos, em parte atribuível à confusão entre Administração e Governo, e a perspectiva do cidadão de obtenção do bem da vida diretamente perante o Poder Judiciário.

De fato, o atual modelo brasileiro consagra o livre acesso ao Judiciário, dadas as garantias fundamentais da inafastabilidade do controle judicial (art. $5^{\circ}, \mathrm{XXXV}$ ), do juiz natural (art. 5, XXXVII e LIII) e do devido processo legal (art. 5, LV). Está-se, portanto, diante de um sistema de jurisdição que, como leciona Moraes, tem como característica básica a possibilidade de pleno acesso ao Poder Judiciário, tanto dos conflitos de natureza privada quanto dos conflitos de natureza administrativa. ${ }^{17}$

O princípio da inafastabilidade do controle judicial tem sua origem na Constituição de 1946, derivando do receio existente, à época, quanto ao ressurgimento do regime do Estado Novo. Daí sua redação em fórmula excessivamente ampla, da qual decorre, na lição de Pontes de Miranda, o fato de que "em todo caso, no sistema jurídico brasileiro, o controle judicial vai muito mais longe do que nos outros sistemas jurídicos, inclusive no dos Estados Unidos da América." 18

A partir da Constituição de 1988, buscou-se incrementar o controle social sobre a Administração Pública; no entanto, o controle social previsto e esperado para a fiscalização

\footnotetext{
${ }^{16}$ ZYMLER, Benjamin. Direito administrativo e controle. Belo Horizonte: Fórum, 2006. p. 400.

${ }^{17}$ MORAES, Alexandre de. Constituição do Brasil interpretada. 2. ed. São Paulo: Atlas, 2003. p. 777.

${ }_{18}$ MIRANDA, Pontes de. Comentários à Constituição de 1967 com a Emenda n. I de 1969. T. 5. 5. ed. São Paulo: Revista dos Tribunais, 1971. p. 106.
} 


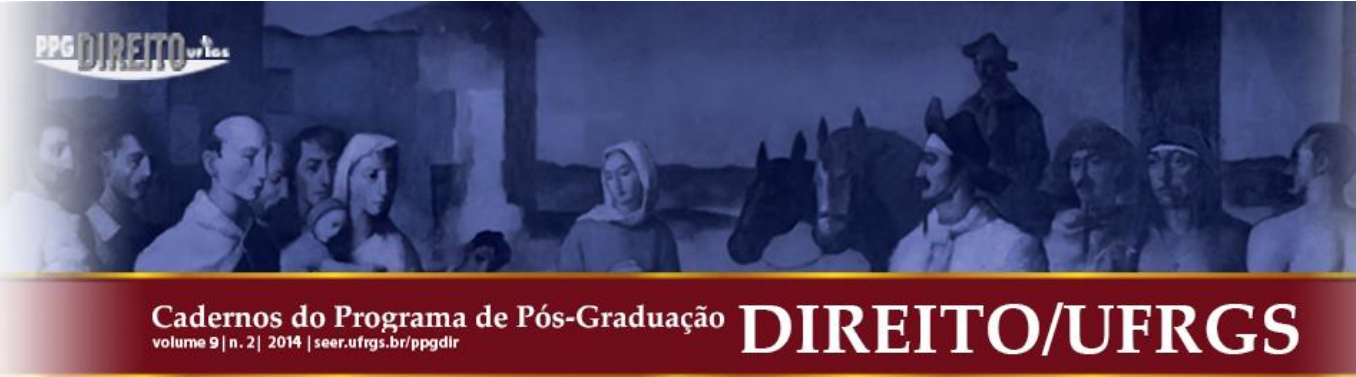

das políticas públicas prevê um nível de organização e mobilização social que, a bem da verdade, a sociedade brasileira ainda não alcançou. Como os instrumentos e as instituições de controle interno do poder, na realidade brasileira, foram relegados a segundo plano, esse incremento findou por se dar via controle externo, e, especificamente, pela via judicial. ${ }^{19}$

Assim, do princípio atualmente previsto no inciso XXXV do art. $5^{\circ}$ da Constituição advém o que recente estudo da Universidade Federal do Rio Grande do Sul para o Conselho Nacional de Justiça denominou de sistema de duplicidade de instâncias: a garantia concomitante do cidadão de valer-se livremente da complexa instância administrativa brasileira e, ao mesmo tempo, encetar ex novo o contencioso com a Administração Pública, por sua iniciativa, frente ao Poder Judiciário. ${ }^{20}$

A existência de esferas diferenciadas pode ser tomada como a outorga ao lesado de uma dupla proteção. ${ }^{21}$ Entretanto, o princípio da inafastabilidade da jurisdição não tem ensejado apenas o desejável controle da atividade administrativa na forma de controle-fiscalização, ou seja, mediante verificação, pelo Judiciário, da atuação administrativa concreta, a fim de apurar sua compatibilidade com as normas gerais e os valores fundamentais. ${ }^{22}$ Tomada como cláusula pétrea, ela tem funcionado como permissivo para a reinterpretação, pelo Judiciário, também de critérios intrinsecamente políticos e, por vezes, afetos às próprias escolhas fundamentais da política social previdenciária.

Ao lado da ampla possibilidade de controle judicial reside, outrossim, a concepção de que cada ação judicial versando sobre matéria previdenciária trata da postulação da própria efetivação, pelo Poder Judiciário, do direito fundamental à previdência social. É disseminada a convicção de que incumbe ao juiz, em demandas tais, sempre uma função protetiva, à vista de um polo ativo hipossuficiente postulando a observância de um direito fundamental a priori tomado como negado, retardado ou mal prestado pelo Estado.

\footnotetext{
19 TORRES, Marcelo Douglas de Figueiredo. Estado, democracia e administração pública no Brasil. Rio de Janeiro: FGV, 2004. p. 82.

${ }^{20}$ BRASIL. Conselho Nacional de Justiça. Universidade Federal do Rio Grande do Sul. As inter-relações entre o processo administrativo e o judicial (em matéria fiscal), a partir da identificação de contenciosos cuja solução deveria ser tentada previamente na esfera administrativa. Relatório Final. Porto Alegre, 2011. Disponível em: <http://www.cnj.jus.br/images/pesquisas-judiciarias/Publicacoes/relat_pesquisa_ ufrgs_edital1_ 2009.pdf.> Acesso em: 31 ago. 2013.

21 MENDES, Gilmar Ferreira; COELHO, Inocêncio Mártires; BRANCO, Paulo Gustavo Gonet. Curso de Direito Constitucional. 2. ed. São Paulo: Saraiva, 2008. p. 1306.

22 JUSTEN FILHO, Marçal. Curso de Direito Administrativo. São Paulo: Saraiva, 2005. p. 740.
} 


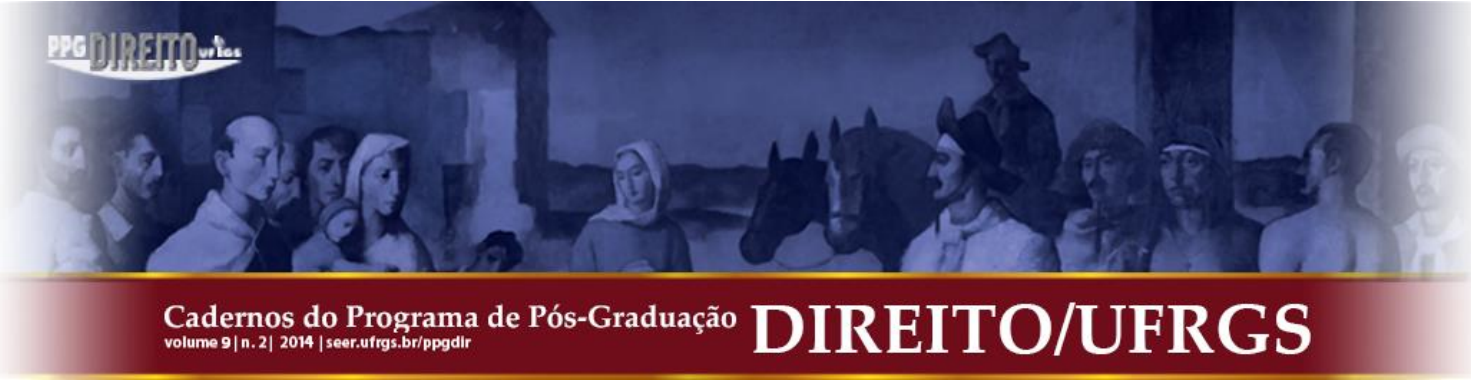

Tal concepção da função jurisdicional em matéria previdenciária encontra suas raízes em uma interpretação absolutamente estendida do princípio do livre convencimento motivado que ora vige no Brasil. Com base nela, permite-se ao juiz, partindo da Constituição, aplicar, no lugar da lei, outro parâmetro de nível e força legal construído a partir de princípios abstratos e gerais ao fato ou à situação em julgamento. ${ }^{23}$ Por sua vez, e a despeito da ressignificação do princípio da legalidade por influxo da Constituição, a Administração segue atuando, em geral, de forma vinculada a uma determinada interpretação da norma. Dada a amplitude dos princípios constitucionais afetos à Administração Pública, o resultado é que "no fundo é o juiz que determina, no caso concreto, o seu alcance. Ou seja, é este que vai especificar, no caso concreto, o seu conteúdo. Assim, já não basta ao administrador cumprir formalmente a lei". ${ }^{24}$

Há, pois, um alargamento da função jurisdicional sobre os atos administrativos afetos às prestações previdenciárias: em vez de uma fiscalização da atuação da Administração e da correção ou não do ato administrativo motivado, o que existe é uma verdadeira atividade de total substituição a que se refere a moderna doutrina processual, no sentido de a decisão do juiz suprir integralmente o ato, o critério ou a decisão administrativa toda vez que o juízo administrativo divergir do seu próprio.

Pleitos afetos ao Regime Geral da Previdência Social e que seriam da rotina da Administração Previdenciária são postos ao Judiciário diuturna e diretamente, a fim de que se decida se estão em conformidade não apenas com sua lei de regência, mas com os respectivos princípios constitucionais. Como a Previdência Social se embasa em filiação obrigatória e abarca grande parte da população brasileira ${ }^{25}$, e levando em conta que as demandas em matéria previdenciária são essencialmente individuais, daí resulta um crescente número de ações judiciais previdenciárias.

\footnotetext{
${ }^{23}$ Como referido no Anteprojeto do Novo Código de Processo Civil, "se todos têm que agir em conformidade com a lei, ter-se-ia, ipso facto, respeitada a isonomia. Essa relação de causalidade, todavia, fica comprometida como decorrência do desvirtuamento da liberdade que tem o juiz de decidir com base em seu entendimento sobre o sentido real da norma." BRASIL. BRASIL. Congresso Nacional. Senado Federal. Comissão de Juristas Responsável pela Elaboração de Anteprojeto de Código de Processo Civil. Brasília: Senado Federal, Presidência, 2010.

${ }^{24}$ FERREIRA FILHO, Manoel Gonçalves. Curso de Direito Constitucional. 35. ed. São Paulo: Saraiva, 2009. p. 239.

${ }^{25}$ O Regime Geral da Previdência Social no Brasil consiste em seguro social que abarca, segundo dados de 2011, 59.239.761 cidadãos, mantendo 26,9 milhões de benefícios ativos. BRASIL. Ministério da Previdência Social. Secretaria de Políticas e Previdência Social. Resultado do Regime Geral de Previdência Social - RGPS. Brasília, dezembro de 2013. Disponível em: <http://www.previdencia.gov.br/politicas-de-previdencia-socialrgps/>. Acesso em: 20 dez. 2013.
} 


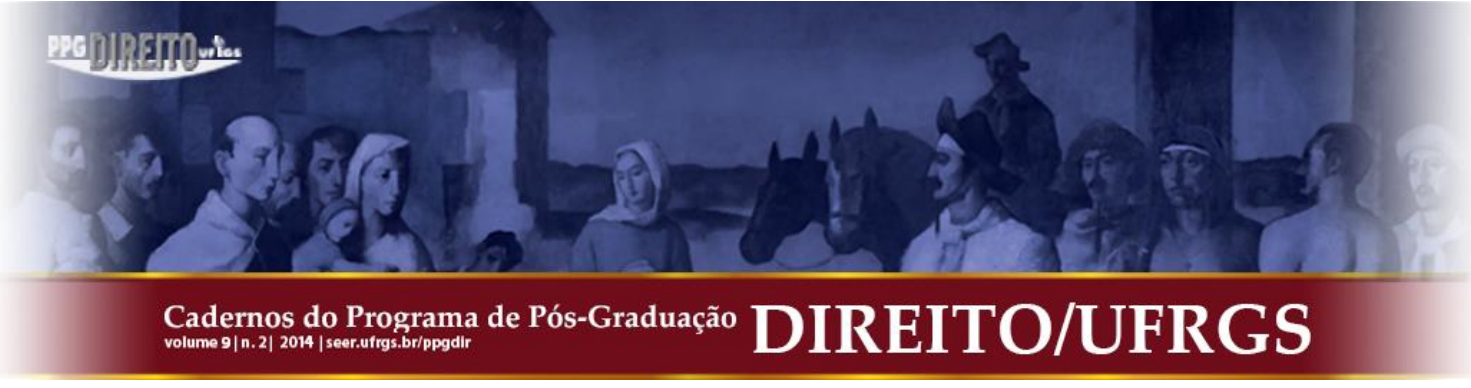

Por outro lado, diante das vastas possibilidades de interpretação próprias das normas abertas e da amplíssima competência dos diversos órgãos jurisdicionais para apreciação dos litígios previdenciários, que tramitam, a um só tempo, na justiça federal e na justiça comum estadual, a consequência é uma regulação judicial singular e distinta dos parâmetros adotados pela Administração em cada caso concreto. Como alerta o já referido estudo da Universidade Federal do Rio Grande do Sul para o Conselho Nacional de Justiça,

\begin{abstract}
À Administração é vedada, como deve ser, declaração de inconstitucionalidade e, máxime, construções constitucionais. Sendo, porém, tais poderes admitidos, em nossa cultura jurídica atual, ao juiz ordinário, mesmo em primeiro grau, cria-se, desde logo, um espaço real e efetivo que tende a opor, crescentemente, a instância administrativa à instância judicial. ${ }^{26}$
\end{abstract}

Num contexto em que cada decisão de um juiz afeta a seu modo a atuação da Administração Pública como um todo - afinal, embora cada demanda traga a questão da efetivação de um direito social em perspectiva individual, a pretensão específica se insere no contexto maior das políticas públicas em matéria previdenciária -, o resultado é uma jurisprudência excessivamente dispersa, que vai ensejar, então, assoberbamento dos tribunais superiores, porque lhes incumbe a uniformização da interpretação da legislação e a última palavra quanto à conformidade da lei à Constituição.

\title{
1.3 A configuração da lide previdenciária
}

Não obstante o volume de ações, a litigiosidade na seara previdenciária não se restringe a demandas repetitivas, ou seja, aquelas em que se veiculam apenas teses jurídicas, sem necessidade de dilação probatória. Ao contrário: a ação previdenciária é "em sua maioria individualizada e quantitativamente representativa, pois os pedidos são veiculados por meio de demandas individuais que repercutem no volume de processos e na morosidade do sistema de justiça brasileiro." ${ }^{27}$ De fato, cada ação judicial traduz uma relação jurídica previdenciária

\footnotetext{
${ }^{26}$ BRASIL. Conselho Nacional de Justiça. Universidade Federal do Rio Grande do Sul. As inter-relações entre o processo administrativo e o judicial (em matéria fiscal), a partir da identificação de contenciosos cuja solução deveria ser tentada previamente na esfera administrativa. Relatório Final. Porto Alegre, 2011. Disponível em: <http://www.cnj.jus.br/images/pesquisas-judiciarias/Publicacoes/relat_pesquisa_ ufrgs_edital1_ 2009.pdf.> Acesso em: 31 ago. 2013.

${ }^{27}$ BRASIL. Conselho Nacional de Justiça. Fundação Getúlio Vargas. Diagnóstico sobre as causas de aumento das demandas judiciais cíveis, mapeamento das demandas repetitivas e propositura de soluções pré-
} 


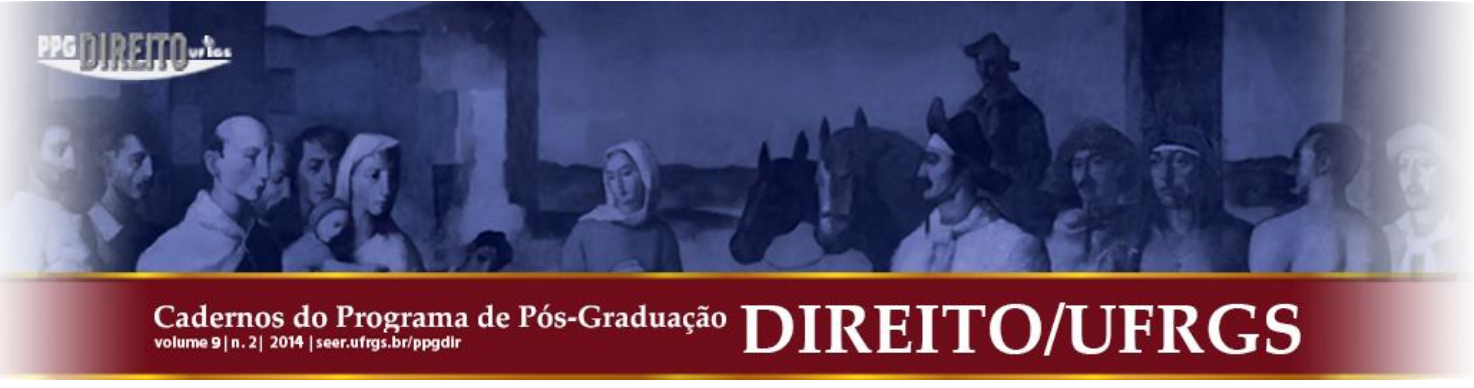

específica; cada cidadão tem seu histórico contributivo e, mais importante, deduz uma pretensão singular de proteção previdenciária em face de um risco social também específico a que foi acometido. ${ }^{28}$

Os diversos fatores externos que concorrem para a conflitualidade previdenciária, ao esmorecerem a noção de lide, findam por influenciar o curso do processo judicial também na sua perspectiva individual.

A imprecisão quanto à própria configuração da lide em matéria previdenciária relaciona-se diretamente com um dos graves problemas afetos aos processos judiciais nessa seara: como regra geral, as demandas são muito mal delimitadas. Em juízo, não é incomum o pleito de reconhecimento, pela parte autora, de todas as circunstâncias de fato afetas à sua pretensão, aí incluídas aquelas já acolhidas pela autarquia previdenciária na esfera administrativa.

De acordo com Savaris, a falta de delimitação do real conteúdo do conflito de interesses estabelecido entre a autarquia previdenciária e o cidadão decorreria da atuação da Administração. Segundo o autor, "a atuação administrativa na análise dos requerimentos de benefícios previdenciários é marcada por uma postura que se distancia dos princípios constitucionais que devem informar sua relação com o particular que busca a proteção previdenciária". Por conseguinte, defende ele, por exemplo, que quando não se faz possível conhecer a razão da rejeição administrativa de uma circunstância específica, ao juiz caberia a assunção da atribuição da Administração, e o julgador, assim, se lançaria ao conhecimento tanto das questões que não foram objeto de exame pela Administração como daquelas que foram rejeitadas sem fundamentação específica. ${ }^{29}$

Concorre para o problema, ainda, a cultura jurídica vigente que, assentada no princípio da proteção judicial, sustenta a possibilidade de postulação de qualquer prestação do cidadão ao Estado diretamente no âmbito judicial. Como extensão da interpretação do conteúdo desse princípio, entende-se, em inúmeras hipóteses, pela desnecessidade mesma de prévio

\footnotetext{
processuais, processuais e gerenciais à morosidade da Justiça. Disponível em: <http://www.cnj.jus.br/images/pesquisas-judiciarias/Publicacoes/ relat_pesquisa_fgv_edital1_2009.pdf>. Acesso em: 13 set. 2013.

${ }^{28}$ Aqui, não se olvida da existência de um sem número de demandas previdenciárias versando sobre matéria unicamente de direito, tais como pleitos de desaposentação ou de revisão da renda mensal de um benefício. No que toca este trabalho, porém, importam as demandas que versam sobre a concessão de um benefício, ou seja, que implicam análise individual e singular do preenchimento, por cada interessado, dos requisitos legais para concessão de uma das benesses concedidas e geridas pelo Instituto Nacional do Seguro Social.

${ }^{29}$ SAVARIS, José Antônio. Direito Processual Previdenciário. 2. ed. Curitiba: Juruá, 2010. p. 72.
} 


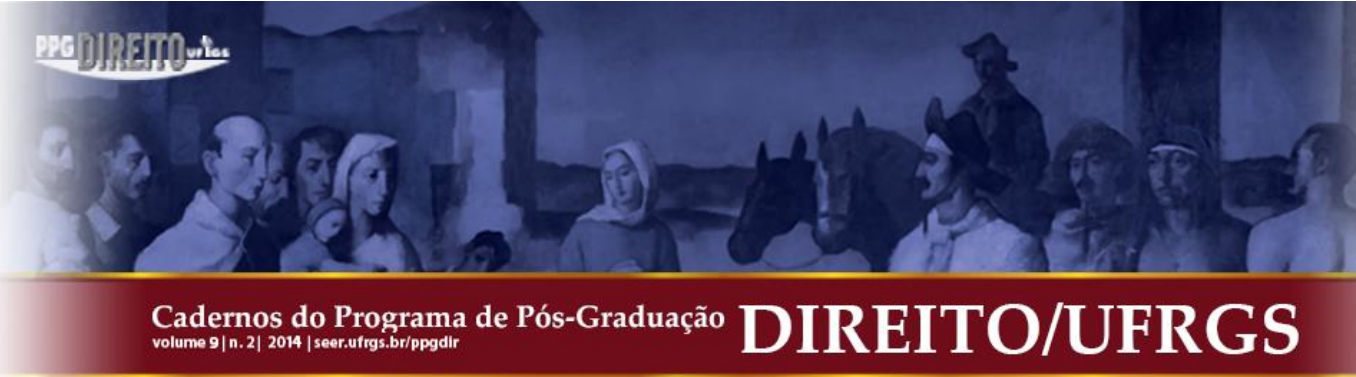

requerimento da prestação perante a autarquia previdenciária: se o cidadão pode valer-se da instância administrativa e, ao final, reconstruir a mesma demanda em face do Poder Judiciário, razão não haveria para que não pudesse ele, desde logo, optar pela via judicial, na medida em que somente esta última faria verdadeira coisa julgada.

Ao fazer as vezes da Administração, o juiz da instância ordinária, dada a proibição do non liquet, se vê instado a realizar uma amplíssima instrução probatória, na medida em que a questão de fundo deixa de ser a correção ou não do indeferimento do benefício pela Administração e passa a consistir na verificação mesma da existência ou não do direito a alguma prestação previdenciária. O resultado é que, em ações previdenciárias, transfere-se ao julgador tarefas típicas da Administração, como analisar e computar todos os períodos de labor constantes de uma Carteira de Trabalho para fins de concessão de benefício de aposentadoria, ainda que, na esfera própria, o fundamento do indeferimento da benesse se restrinja à não-confirmação de um único vínculo de emprego. A par de ensejar o prolongamento da lide previdenciária, tal postura em nada contribui para o aperfeiçoamento da atuação da Administração; ao contrário, acaba fomentando o incremento do volume de demandas judiciais.

Em última análise, o alargamento da atuação do Judiciário em sua função típica de controle externo da atuação da Administração, que deveria agir no aperfeiçoamento da gestão da política pública previdenciária, ocasiona insegurança jurídica à atuação administrativa e ineficiência à máquina judiciária. Olvida-se que o interesse público a ser protegido na seara previdenciária reside tanto na correta aplicação dos recursos afetos a esta política pública como na proteção ao direito fundamental à prestação previdenciária de natureza alimentar, perdendo, com isso, o Estado Democrático de Direito, cuja existência depende, para a efetividade dos direitos e garantias sociais, do bom funcionamento de ambas as esferas. Daí deriva a necessidade de as especificidades da relação jurídico-previdenciária serem levadas em conta no emprego das técnicas processuais, como condição para que se assegure uma tutela jurisdicional adequada e efetiva.

\section{A TUTELA JURISDICIONAL PREVIDENCIÁRIA}

\subsection{Aproximação das esferas administrativa e judicial e correta delimitação da lide}




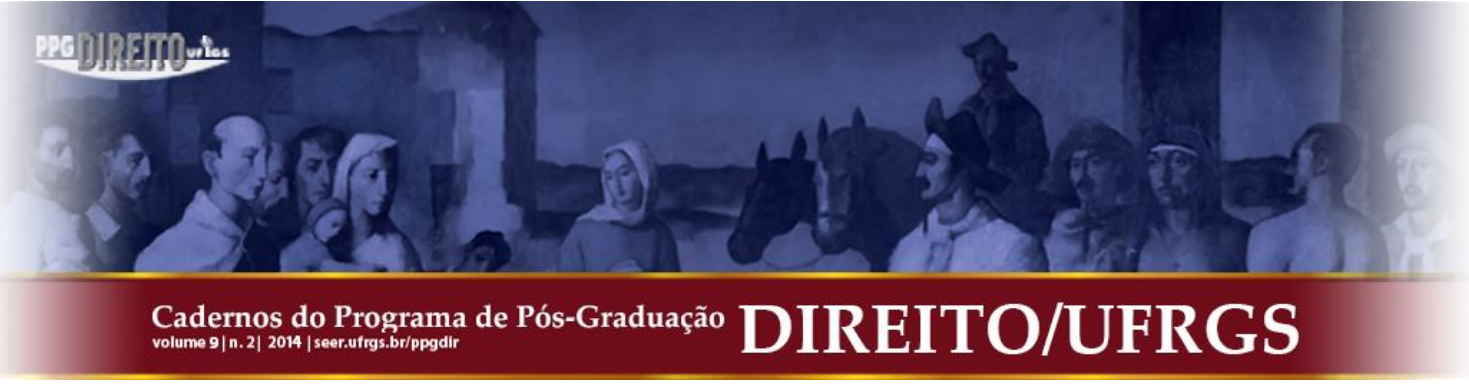

O desenvolvimento mais recente do processo civil reflete uma preocupação de reconhecimento da instrumentalidade dos mecanismos processuais em relação ao direito material subjacente. Além da adequação formal das normas procedimentais, introduz-se como questão prioritária a capacidade do processo de produzir resultados consistentes com as necessidades do ordenamento de direito material.

$\mathrm{Na}$ exata proporção em que há um crescente número de lides regidas primordialmente pelo direito material público, aí incluídas as ações previdenciárias, um processo civil voltado tradicionalmente para a solução de conflitos regidos pelo direito material privado pode levar, em curto espaço de tempo, à sua ineficiência ou ineficácia. ${ }^{30}$ É que o processo civil foi estruturado e sistematizado a partir de conflitos de direito privado, e o atual Código de Processo Civil, pensado para as lides civis. As reformas processuais operadas nos últimos anos lhe trouxeram maior aptidão para a noção de processo coletivo e, em alguma medida, adequação frente à garantia da razoável duração dos processos. Remanescem, contudo, os problemas da sua aplicação às relações litigiosas de direito público. Na lição de Rosemiro Pereira Leal, há "a inteira indiferença que hoje se percebe ao surgimento de novos ramos do direito, de direitos novos e inovadores, mantendo-se um Código Processual de teleologia civilista, quando já deveríamos ter um Código de Processo Geral". ${ }^{31}$

Em matéria previdenciária, não há disputa entre indivíduos privados sobre direitos privados, mas uma pretensão de concretude de uma política pública, que, ante a verticalidade da relação jurídica posta em juízo, põe em evidência o alcance (e os limites) da atuação jurisdicional em face das atividades-fim da Administração. ${ }^{32}$ Não se está, portanto, diante de um modelo tradicional de litigância, no qual a ação judicial é bipolar, com dois interesses em posições diametralmente opostas, e retrospectiva, ou seja, relacionada a eventos passados. ${ }^{33}$ Reconhece-se, pois, que o direito processual previdenciário, assim como o que se denomina

\footnotetext{
${ }^{30}$ BUENO, Cassio Scarpinella Bueno. Processo Civil de interesse público: uma proposta de sistematização. In: SALLES, Carlos Alberto de (Org.). Processo Civil e Interesse Público: o processo como instrumento de defesa social. São Paulo: Revista dos Tribunais, 2003. p. 24.

${ }^{31}$ LEAL, Rosemiro Pereira. Teoria Geral do Processo: primeiros estudos. São Paulo: Síntese, 1999. p. 86.

${ }^{32}$ Encerra-se, aqui, a tensão entre micro e macro justiça e entre os paradigmas protetivo e consequencialista a que se refere Gustavo Amaral, cuja abordagem transcenderia os limites deste trabalho. Vide AMARAL, Gustavo. Direito, escassez e escolha: critérios jurídicos para lidar com a escassez de recursos e as decisões trágicas. 2. ed. Rio de Janeiro: Lúmen Juris, 2010. p. 184.

${ }^{33}$ SALLES, Carlos Alberto de. Processo civil de interesse público. In: SALLES, Carlos Alberto de. (org.). Processo Civil e Interesse Público: o processo como instrumento de defesa social. São Paulo: Revista dos Tribunais, 2003. p. 45.
} 


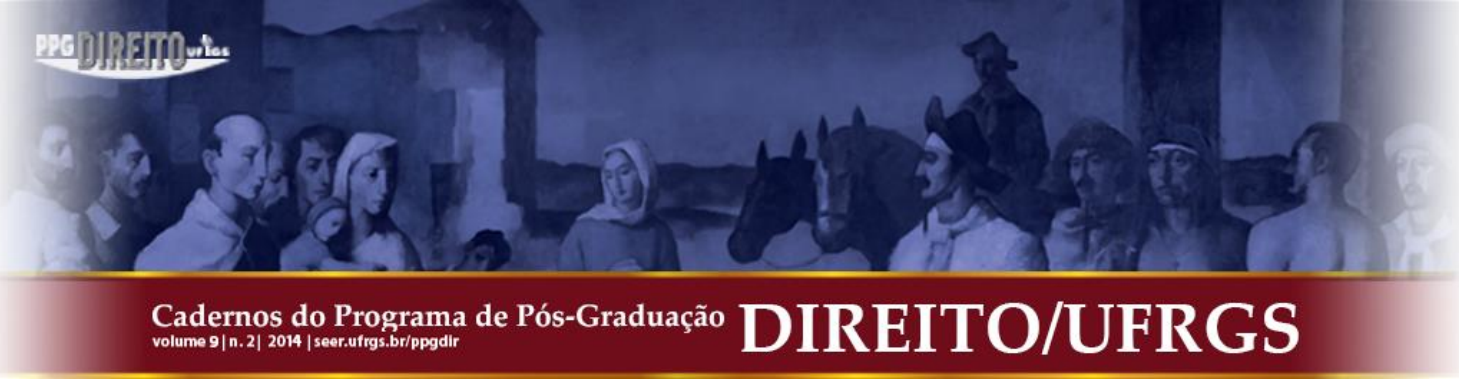

direito processual público ${ }^{34}$, possui especificidades que lhe distinguem do processo civil tradicional.

À vista disso, uma primeira questão afeta à inadequação do processo judicial previdenciário diz com o fato de que ele tem permitido, senão acentuado, a perpetuação da absoluta independência e, no mais das vezes, ausência de qualquer inter-relação entre a esfera administrativa e a judicial. A partir da Emenda Constitucional n. ${ }^{\circ} 19 / 98$ e especialmente após o advento da Lei n..$^{\circ}$ 9.784/99, eficiência e processualidade da atuação administrativa passaram a ser faces de uma mesma moeda, e a tônica da produção dos atos administrativos passou a ser dada pelo iter procedimental percorrido. ${ }^{35} \mathrm{O}$ processo passou a ser instrumento indispensável para o exercício de uma função administrativa; logo, toda a atuação administrativa necessariamente deve se desenvolver por meio dele, tendo por finalidade a expedição de um determinado ato administrativo. ${ }^{36}$

Assim, a configuração de uma lide pública previdenciária não se confunde nem com a mera aspiração do cidadão a um benefício, nem com a tão-só existência de um processo administrativo prévio à manifestação final, porque não se pode precisar, desde a origem, se haverá ou não resistência à pretensão do postulante. A lide pública passível de solução pelo Poder Judiciário surge quando a pretensão deduzida perante a Administração e analisada no bojo de um processo administrativo é fundamentadamente indeferida. Por esse viés, o processo administrativo que culminou na decisão administrativa contrária aos interesses do cidadão ou, dito de outro modo, que deu origem à lide previdenciária, pode e deve servir de

\footnotetext{
${ }^{34} \mathrm{Na}$ acepção dada ao termo por Carlos Ari Sundfeld e Cassio Scarpinella Bueno, ou seja, a parte do direito processual que regula os processos judiciais que tenham ou como objeto o Direito Público ou como parte a Administração Pública. Sobre o tema, v. Direito processual público: a Fazenda Pública em Juízo. São Paulo: Malheiros, 2000 e BUENO, Cassio Scarpinella. Curso sistematizado de direito processual civil. v. 1. 8. ed. São Paulo: Saraiva, 2014. p. 67-70.

${ }^{35}$ BUENO, Cassio Scarpinella. Inafastabilidade do controle judicial da Administração. In: SUNDFELD, Carlos Ari e BUENO, Cassio Scarpinella (Org.). Direito processual público: a Fazenda Pública em Juízo. São Paulo: Malheiros, 2000. p. 246.

${ }^{36}$ Destarte, embora a carta de indeferimento de um benefício previdenciário explicite tão-somente o fundamento, mas não a fundamentação para a negativa da pretensão do cidadão, a concisão de tal documento não infirma a constatação de que atualmente a Administração Pública não pode mais ser vista como mera produtora aleatória de atos administrativos, mas sim enquanto produtora racional de atos administrativos derivados de regulares processos administrativos. Dada sua natureza de atividade estatal vinculada à lei e destinada a garantir um direito social, afigura-se plenamente exigível uma postura imparcial e proativa da Administração, reconhecendo o direito ao benefício ou serviço sempre que os requisitos legais se fizerem presentes e, se necessário, buscando elementos que esclareçam os fatos narrados pelo segurado por ocasião do seu requerimento administrativo. Sobre o tema, vide PEREIRA, Frederico Valdez. Processo administrativo de concessão de benefício previdenciário: noção e princípios de legitimação da atuação do INSS. In: VAZ, Paulo Afonso Brum e SAVARIS, José Antonio (Org.). Curso modular de direito previdenciário. v. 2. Florianópolis: Conceito, 2010. p. 313.
} 


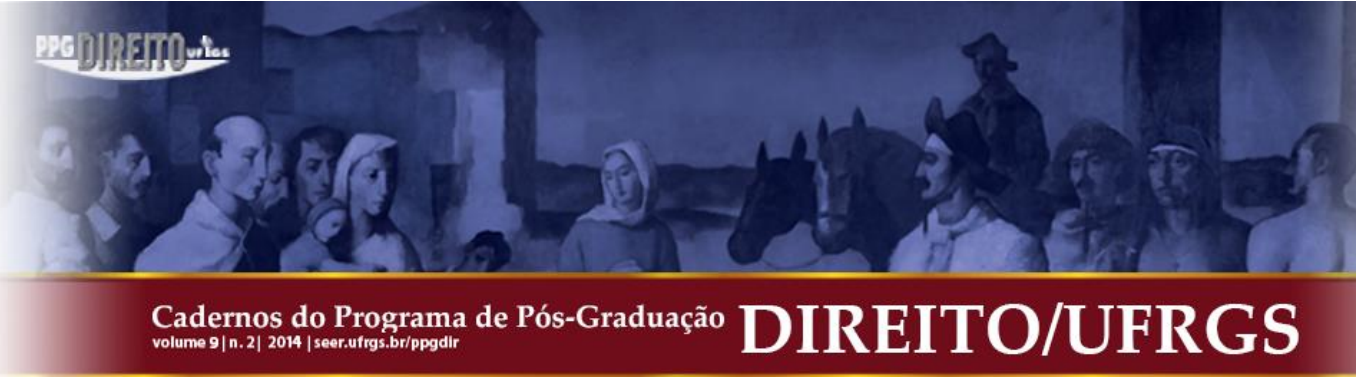

baliza para a definição dos pontos controvertidos a serem dirimidos pelo juízo. Partindo-se do pressuposto de que a Administração não agiria de forma deliberada para prejudicar um segurado, não haveria razão legítima para não se dar crédito às informações constantes do procedimento administrativo. ${ }^{37}$

Repousa aqui a importância de uma visão aproximativa entre o processo administrativo e o processo judicial, a fim de que as notas características da lide pública previdenciária reflitam não apenas na necessidade de observância das prerrogativas processuais da Fazenda Pública, mas para que também ajam positivamente como pautas otimizadoras do processo. Por esse prisma, o processo administrativo serviria de parâmetro para fixação da extensão da controvérsia judicial, delimitando a lide e racionalizando, assim, as atividades judiciais; os atos processuais realizados com a participação do cidadão na esfera administrativa seriam aproveitados na via judicial para o correto direcionamento da instrução probatória; e as insuficiências da atuação administrativa seriam corrigidas, e não substituídas, pelo Poder Judiciário, em verdadeira atividade de controle externo sobre uma atividade tipicamente administrativa.

Em realidade, porém, à exceção do procedimento dos juizados especiais federais, em que a juntada dos documentos essenciais à lide decorre de disposição legal expressa ${ }^{38}$, nas ações ordinárias o processo administrativo muitas vezes sequer aporta ao processo judicial. Com base no entendimento de que cabe ao juízo analisar, ainda que de forma inédita, o direito ou não a alguma prestação previdenciária, olvida-se que inúmeros atos já foram ou deveriam ter sido realizados, na via administrativa e com participação do segurado, com o mesmo desiderato.

Tome-se como exemplo a repetição, em juízo, da tomada da prova oral já produzida por ocasião da justificação administrativa. Prevista no art. 108 da Lei n. ${ }^{\circ}$ 8.213/91, a justificação administrativa é o meio utilizado para suprir a falta ou insuficiência de documento ou outra circunstância de interesse previdenciário, quando não se faz possível a obtenção de meios razoáveis ou acessíveis para sua demonstração. Ela tem, portanto, função probatória

\footnotetext{
${ }^{37}$ TAVARES, Marcelo Leonardo. Direito Previdenciário. 12. ed. Niterói: Impetus, 2010. p. 33-38.

${ }^{38}$ Trata-se da obrigação constante do art. 11 da Lei n. 10.259/2001, segundo o qual a entidade pública ré deverá fornecer ao Juizado a documentação de que disponha para o esclarecimento da causa, apresentando-a até a instalação da audiência de conciliação.
} 


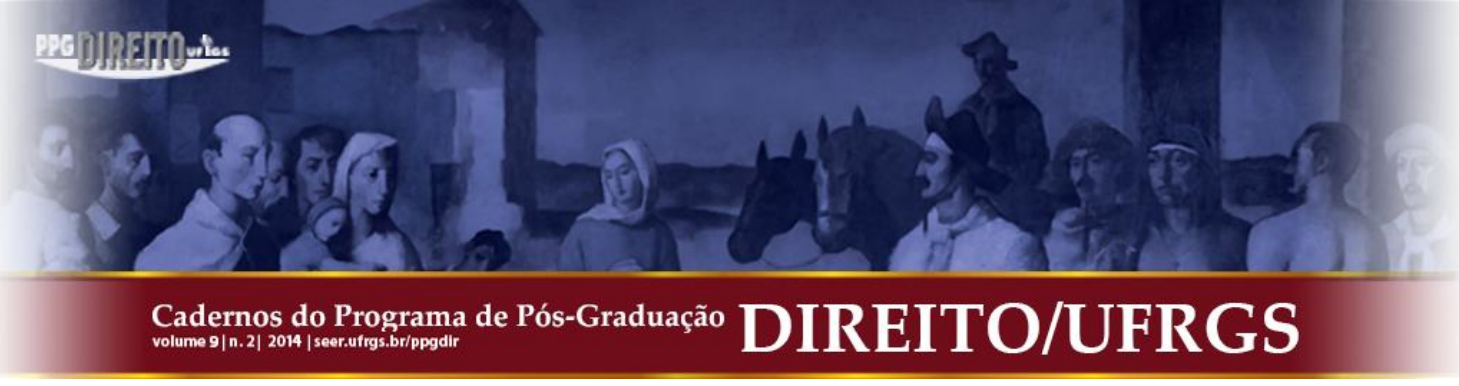

complementar para as hipóteses em que a legislação não permite apenas prova testemunhal, exigindo início de prova material. ${ }^{39}$

Uma vez produzida a justificação administrativa na via e no tempo próprios, desnecessária a repetição do ato na esfera judicial, porque o segurado já participou ativamente de sua produção perante a autarquia. De outra parte, quando, embora requerida pelo segurado, a justificação não é levada a efeito pelo INSS, mais correta a determinação de reabertura do processo administrativo para sua realização, porque, nesse caso, o Poder Judiciário estará influindo positivamente na correção do procedimento de análise do benefício. ${ }^{40}$

Nessa mesma linha, defensável a posição de que, verificado vício de forma a ensejar a nulidade do ato administrativo, como nas hipóteses de supressão do contraditório em processos administrativos que apuram irregularidades na concessão de um benefício, a solução judicial deveria ser a declaração de nulidade do ato. Com efeito, se o poder Judiciário, ao invés de anular o ato, passa a decidir a questão de fundo, o administrado continua sem a observância da garantia do contraditório no procedimento administrativo. ${ }^{41}$

Nesse contexto, ganha importância a retomada da temática do interesse de agir. Assumido como interesse-adequação, ele serve de filtro de eficiência por meio do qual se evita o dispêndio de atividade jurisdicional inútil. Em outros termos, o correto estabelecimento da lide permite que a discussão afeta ao interesse processual em matéria previdenciária saia do âmbito da negativa de jurisdição ou de ofensa ao direito de ação e passe a ser analisado pelo prisma da impropriedade da via jurisdicional, uma vez que não faz sentido colocar o aparato judicial para atender interesses que podem e devem ser supridos pela atuação do Instituto Nacional do Seguro Social.

Até há pouco, a jurisprudência do Superior Tribunal de Justiça sancionava uma disseminada atuação do Judiciário voltada para a verdadeira e integral substituição da autarquia previdenciária, recentemente passou a reconheceu a necessidade de prévio

\footnotetext{
${ }^{39}$ MARTINS, Sergio Pinto. Direito da Seguridade Social. 20. ed. São Paulo: Atlas, 2004. p. 470 . A súmula 149 do STJ assenta que "a prova exclusivamente testemunhal não basta à comprovação da atividade rurícola, para efeito de obtenção de benefício previdenciário". Assim, a justificação administrativa é utilizada, de maneira geral, como prova (ainda que não exclusiva) de tempo de serviço e de situações de união estável.

${ }^{40}$ Desnecessárias ambas as providências, porém, quando, na delimitação do cerne da controvérsia, verifica-se desde logo que o indeferimento do benefício decorreu não da ausência ou insuficiência da prova oral produzida na justificação, mas da inexistência de início de prova material, requisito indispensável para a comprovação de algumas situações previdenciárias. Nessa última hipótese, a solução da controvérsia pode se ater, sem qualquer prejuízo às partes, à valoração da prova documental produzida em ambas as esferas.

${ }^{41}$ Esse entendimento já foi acolhido pelo STF no MS 24268/MG, Pleno, rel. Min. Gilmar Mendes, j. 05.02.2004.
} 


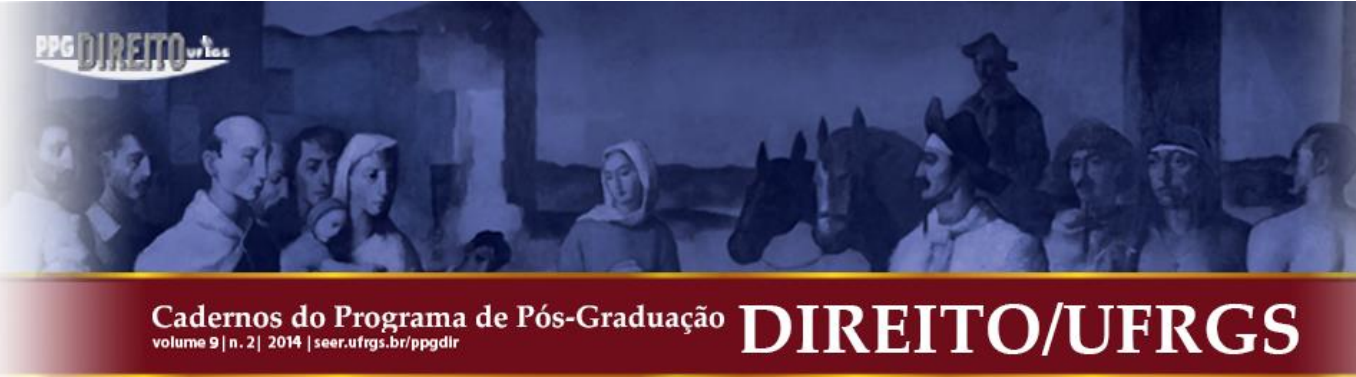

requerimento administrativo como condição para postular nas vias judiciais. Ganhou espaço, aos poucos, o entendimento de que o interesse processual do segurado e a utilidade da prestação jurisdicional concretizam-se basicamente nas hipóteses de recusa de recebimento do requerimento e negativa de concessão do benefício previdenciário, seja pelo concreto indeferimento do pedido, seja pela notória resistência da autarquia à tese jurídica esposada. ${ }^{42}$

Recentemente, porém, o Supremo Tribunal Federal, ao julgar o RE 631240-MG em sede de repercussão geral $^{43}$, espancou qualquer confusão ainda existente entre postulação e exaurimento das vias administrativas e julgou necessário o prévio requerimento do interessado perante o INSS como condição de ação. A reconhecida recalcitrância da jurisprudência sobre o tema, porém, exigiu daquela corte a instituição de uma sistemática transitória para ações já em curso sem que tivesse havido prévio requerimento administrativo, a qual, em linhas gerais, consistiu no sobrestamento do feito até que ultimado o pedido perante a Administração.

Por certo, remanescem hipóteses em que não tem cabimento entender-se pela falta de interesse de agir, as quais, em linhas gerais, dizem com aquelas pretensões cujo indeferimento administrativo é certo ou notório. Aliás, o julgado do Supremo faz expressa referência a essas situações. Por evidente, também não se sustenta a impossibilidade de o Judiciário, quando provocado, emitir provimento jurisdicional que substitua um ato administrativo por antijuridicidade, ou mesmo de emiti-lo de forma primeira em caso de inércia desarrazoada do Poder Público. Defende-se, porém, o estabelecimento de uma relação de funcionalidade intrínseca entre processo e norma material e entre Judiciário e Administração, visando ao aperfeiçoamento da gestão da política pública previdenciária. Por este prisma, afora esses casos excepcionais, em que a prescindibilidade do prévio requerimento não afeta a configuração da lide previdenciária, não se vê fundamento legítimo para que se transfira para a máquina judiciária a realização da atividade-fim afeta à concretização da política pública previdenciária.

\footnotetext{
42 STJ, REsp 1310042/PR, Rel. Min. HERMAN BENJAMIN, Segunda Turma, julgado em 15/05/2012, DJe 28/05/2012; AgRg no AREsp 283.743/AL, Rel. Min. CASTRO MEIRA, Segunda Turma, DJe 26/04/2013, dentre outros.

${ }^{43}$ Tema 350 - Prévio requerimento administrativo como condição para o acesso ao Judiciário, tendo como relator o Min. Roberto Barroso. O recurso extraordinário fora autuado ainda em 11.10.2010 e a repercussão geral fora reconhecida em decisão datada de 10.12.2010.
} 


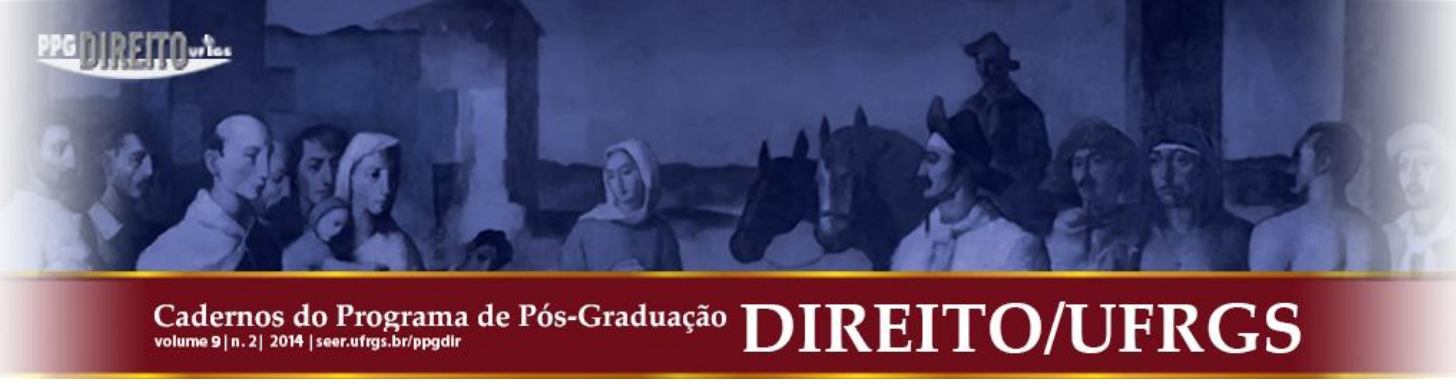

\subsection{Inadequação de procedimentos e excesso de instrução probatória}

As formas procedimentais essenciais devem ser certas e determinadas, especialmente porque o procedimento brasileiro é do tipo rígido; não devem, porém, sufocar a naturalidade e rapidez do processo. ${ }^{44}$ Daí porque, na exata medida em que o direito material se modifica substancialmente no campo do direito público, as normas processuais civis precisam ser revistas, relidas e reinterpretadas, para que possam realizar os direitos materiais. ${ }^{45}$

Por esse prisma, o direito constitucional a procedimentos adequados ${ }^{46}$ e o advento do procedimento sumaríssimo dos juizados especiais federais permitem alguma reflexão com relação à conformação dos diversos procedimentos afetos à relação jurídico-previdenciária.

A obediência ao procedimento ordinário em matéria previdenciária, ou seja, o atentar para a ordem dos atos processuais na forma posta na atual legislação, ao não levar em conta as particularidades dessa relação jurídica, tem dado ensejo a um processo que, além de não propiciar condições para a conciliação entre as partes, assume ao longo da instrução processual uma complexidade que não condiz com a natureza alimentar do direito postulado. ${ }^{47}$

Veja-se, a título de ilustração, que uma demanda que versa sobre benefício por incapacidade pode ter uma condução procedimental absolutamente distinta, a depender se proposta no juizado especial federal, com seu rito especialíssimo, numa vara federal ou numa vara da justiça comum ${ }^{48}$. Em todas essas demandas, a pretensão deduzida na inicial é similar, assim como foi o procedimento observado na via administrativa; o que as diferencia é o valor da causa, que sofre alteração em razão da renda mensal do benefício postulado, a existência

\footnotetext{
${ }^{44}$ CINTRA, Antonio Carlos de Araújo; GRINOVER, Ada Pellegrini; DINAMARCO, Candido Rangel. Teoria Geral do Processo. 29. ed. São Paulo: Malheiros, 2013. p. 34 e 358.

${ }^{45}$ BUENO, Cassio Scarpinella Bueno. Processo Civil de interesse público: uma proposta de sistematização. In: SALLES, Carlos Alberto de (Org.). Processo Civil e Interesse Público: o processo como instrumento de defesa social. São Paulo: Revista dos Tribunais, 2003. p. 25.

${ }^{46}$ Da forma posta no art. 98, I, da Constituição da República.

${ }^{47}$ Dada a demora na prestação jurisdicional, a concessão ou negativa dos efeitos da antecipação da tutela, e não a decisão definitiva, é que passa a ser o verdadeiro ponto central da demanda. Via reflexa, a conciliação também se inviabiliza, quer porque a tutela antecipada, fundada na quase-certeza da demora na prestação jurisdicional final, torna-se uma regra, quer porque o momento propício para a Administração transacionar somente se verifica depois de encerrada a regular instrução processual, coincidindo, então, com o próprio momento de sentenciar. A revogação da tutela antecipada por ocasião de eventual decisão de improcedência traz como reflexo, ainda, infindáveis discussões acerca da repetitividade ou não dos valores alcançados ao segurado ao longo do processo e sobre os efeitos previdenciários decorrentes do gozo precário de um benefício.

${ }^{48}$ Neste último caso, em face da competência delegada prevista no art. 109, §3º da Constituição da República.
} 


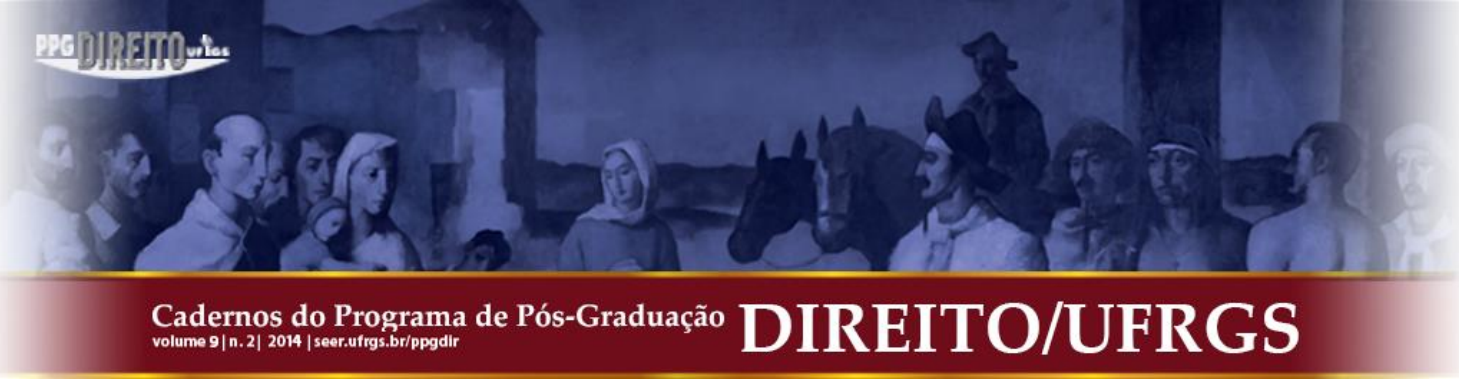

ou não de uma vara federal instalada na localidade e, em grande medida, também a postura assumida pelo juiz da causa e pelas demais partes envolvidas.

Como é recorrente ocorrer no âmbito dos juizados especiais, um procedimento invertido no qual se realiza desde logo a prova pericial e, a seguir, confronta-se seu resultado com o ato administrativo indeferitório previamente acostado aos autos pela autarquia previdenciária cria condições para a solução definitiva da lide em poucos meses, seja via conciliação, seja via sentença de mérito. Estando-se diante de ação proposta numa vara comum que atenta para todo o trâmite do procedimento ordinário, porém, a prova fundamental para o deslinde da controvérsia acaba sendo realizada, no mais das vezes, mais de um ano depois da propositura da demanda ${ }^{49}$, e muitas outras depois de realizada uma audiência preliminar de conciliação que se sabe, desde logo, infrutífera, dada a ausência, nesse momento processual, de qualquer prova judicializada contrária à decisão administrativa. ${ }^{50}$

Como se vê, é por ocasião da instrução probatória que toda a complexidade da demanda previdenciária se revela, já que "a atribuição de um direito previdenciário pressupõe laboriosa tarefa de exame de fatos." ${ }^{51}$ Quando não são delimitados, desde logo, o cerne da controvérsia, os meios de prova necessários para sua solução e a respectiva distribuição dos ônus probatórios, o resultado é uma maior dificuldade para o próprio sentenciamento, haja vista o acúmulo de informações inúteis que resultam da produção de provas dispensáveis. ${ }^{52}$ Avulta no campo instrutório, portanto, a importância do diálogo judicial na formação do juízo, por

\footnotetext{
${ }^{49}$ Embora há muito a doutrina sustente que, em matéria previdenciária, a própria realização da perícia pode ser antecipada à resposta sem que haja, nessa atitude, nulidade. PEREIRA, Hélio do Valle. Manual da Fazenda Pública em Juízo. Rio de Janeiro: Renovar, 2003. p. 535.

${ }^{50}$ Semelhante problema ocorre nas ações para obtenção de benefícios acidentários. Conquanto tais demandas não difiram, em essência, das ações nas quais se postulam benefícios previdenciários (seu traço distintivo é tãosomente a natureza acidentária que origina a pretensão), são elas, por força constitucional (art. 109, I, da CR), de competência absoluta da justiça comum estadual, sendo-lhes prevista, ademais, a aplicação do rito sumário. Se ambas estas decisões do legislador tinham alguma razão de ser no passado, hoje se afigura evidente a impropriedade do tratamento conferido às causas acidentárias. Primeiro, porque a justiça federal já se encontra suficientemente aparelhada para seu processamento; segundo, porque o rito sumário previsto na lei apenas implica a indicação dos meios de prova desde logo e a realização de uma audiência inaugural com finalidade conciliatória. Como qualquer tentativa de composição da lide previdenciária será infrutífera antes de produzida qualquer prova judicializada que comprove o requisito que, por ausente na via administrativa, embasou o indeferimento da prestação, o procedimento sumário se iguala ao ordinário em termos de inadequação para uma tutela jurisdicional eficiente em matéria previdenciária.

${ }^{51}$ SAVARIS, José Antonio. Algumas reflexões sobre a prova material previdenciária. In: Instituto Brasileiro de Direito Previdenciário (Coord.). Direito Previdenciário em debate. Curitiba: Juruá, 2008. p. 53-54.

${ }^{52}$ SILVEIRA, João José Custódio da. O juiz e a condução equilibrada do processo. São Paulo: Saraiva, 2012. p. 137.
} 


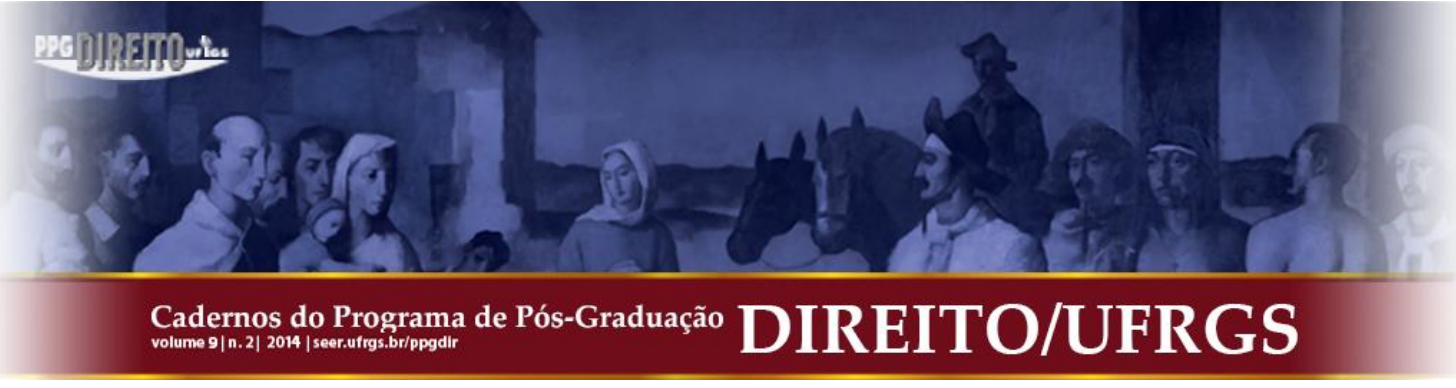

Decerto não se afirma que o direito à prova deve ser mitigado em matéria previdenciária. $\mathrm{O}$ direito à prova, porque derivado dos direitos fundamentais ao contraditório e ao acesso à justiça, erige-se como direito fundamental; é por meio dele que se garante ao cidadão uma adequada participação no processo. No entanto, o direito ao manejo das provas, independentemente de quem as postula, deve levar em conta sua relevância para a tutela do bem perseguido, pelo que, por aplicação do princípio da economia, há de ser verificada sempre sua utilidade e seu cabimento. Assim, quando não há controvérsia quanto aos fatos alegados, ou quando a prova é impertinente ou irrelevante, plenamente justificável o seu indeferimento.

Ainda no campo probatório em matéria previdenciária, sobressaem, à vista de uma visão mais publicista do processo, voltada para sua efetividade, os poderes instrutórios do juiz, que devem servir para direcionar a apuração dos fatos que lhe são postos para análise. Exemplo típico são as situações em que a melhor prova para a resolução da demanda está em poder de terceiros, como ocorre nas causas em que se objetiva o reconhecimento do caráter especial do trabalho e, não raro, verifica-se a impossibilidade ou dificuldade do autor de obter a prova documental necessária para análise do pleito. A obtenção dessa documentação via requisição à empresa é o meio de prova mais fidedigno e menos oneroso para o processo; ainda assim, no mais das vezes o autor postula e o juízo determina sua substituição pela realização de uma complexa prova pericial..$^{55}$

As dificuldades resultantes do excesso de instrução processual para a decisão do processo abrem espaço para o indesejável recurso a presunções que supostamente sinalizariam a forma de valoração das provas produzidas. Por vezes, faz-se alusão ao princípio da supremacia do interesse público sobre o privado, o que, em sede de processo previdenciário, se traduziria em critério favorável aos argumentos da Administração, mesmo quando ausente uma argumentação intersubjetivamente justificada para dar-lhe respaldo ${ }^{56}$; noutras, tem

\footnotetext{
${ }^{55}$ Nesses casos, por força de lei, a comprovação do exercício do trabalho com submissão a agentes nocivos se dá por meio de formulários preenchidos pelo empregador ou preposto, os quais descrevem as atividades do empregado e as condições do ambiente de trabalho. Ainda assim, em geral o juiz assume uma postura passiva diante da perícia, muito embora "a perícia é prova onerosa, complexa e demorada. Por isso, só deve ser admitida quando imprescindível para elucidação dos fatos. Toda vez que se puder verificar a verdade dos fatos de forma mais simples e menos custosa, a perícia deve ser dispensada.” DIDIER JR., Fredie; BRAGA, Paula Sarno e OLIVEIRA, Rafael. Curso de Direito Processual Civil. v. 2. Salvador: JusPodium, 2007. p. 186.

${ }^{56}$ De acordo com Tavares, tal posicionamento pode ser encontrado em decisões judiciais que mantêm atos de cancelamento de benefícios previdenciários que, em verdade, são vazios na fundamentação das razões do ato de declaração de nulidade da concessão anterior do benefício. "Assim, desde que a Administração observasse o rito
} 


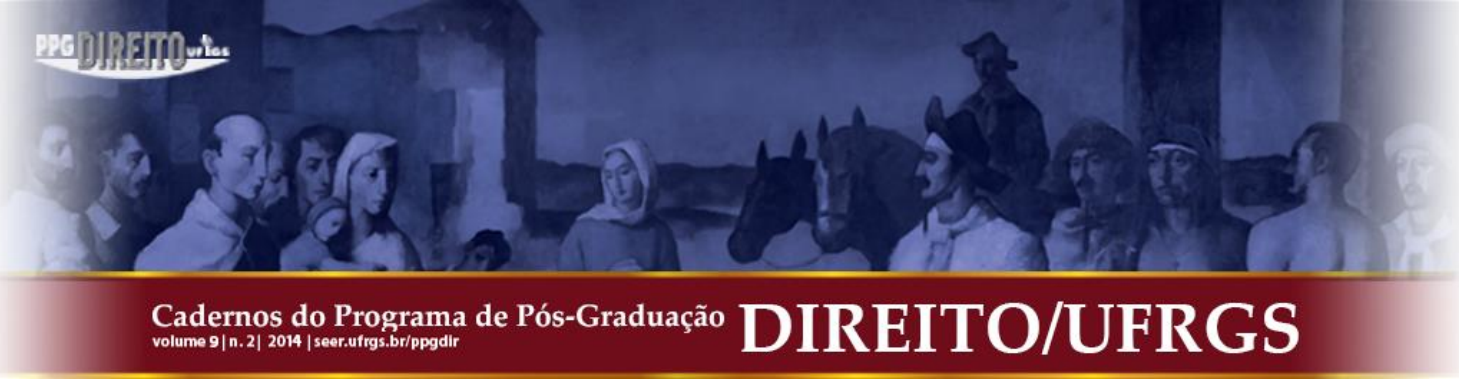

assento um também suposto princípio in dubio pro misero ${ }^{57}$, a ensejar o acolhimento da pretensão em caso de dúvida quanto ao preenchimento dos requisitos para sua concessão. Nas duas situações, porém, corre-se o risco de a decisão final não corresponder à decisão mais justa.

\subsection{Um direito processual previdenciário?}

Se são inúmeros os problemas atuais na condução das demandas previdenciárias, no campo do cumprimento da decisão substanciais foram os avanços alcançados nos últimos anos. O crescente número de sentenças condenatórias impôs à autarquia a criação de um aparato dedicado especificamente ao seu pronto cumprimento ${ }^{58}$ e ao fornecimento de subsídios para a defesa judicial do Instituto. Com o mesmo desiderato, o Conselho Nacional de Justiça e o Conselho da Justiça Federal passaram a recomendar que as decisões judiciais em face da autarquia contenham elementos mínimos que permitam seu célere cumprimento. ${ }^{59}$

Difundiu-se, no segundo grau de jurisdição, a concessão de tutela específica ${ }^{60}$ determinando o imediato cumprimento das obrigações de fazer nas ações concessórias de benefícios, assim como se consolidou, na execução, o chamado procedimento invertido, por meio do qual, após o trânsito em julgado do título judicial, a autarquia é intimada para

previsto em lei, não teria o ônus de demonstrar no que consistem seus elementos de convencimento". TAVARES, Marcelo Leonardo. Direito Previdenciário. 12. ed. Niterói: Impetus, 2010. p. 33-38.

${ }^{57} \mathrm{Na}$ esfera trabalhista, a regra in dubio pro operario ou in dubio pro misero tem lugar quando há divergência de interpretação em relação a uma norma jurídica aplicável ao caso concreto, hipótese em que se dará preferência então àquela interpretação que mais favoreça o empregado. No entanto, "esta regra deve ser aplicada no âmbito do direito material do trabalho e jamais no que se refere ao direito processual laboral, onde as partes devem merecer tratamento isonômico". CAIRO JR., José. Curso de Direito do Trabalho. 2. ed. Salvador: JusPodium, 2008. p. 91. Assim, na sua origem, essa regra/princípio/presunção somente tem aplicação quando houver fundada dúvida a respeito do alcance da lei, e nunca para suprir deficiências da prova, tampouco quando implicar sacrifício do interesse público em função do interesse particular.

58 Trata-se das Agências da Previdência Social de Atendimento de Demandas Judiciais - APSADJ e Setores de Atendimento de Demandas Judiciais - SADJ, instalados nas localidades onde há Vara da Justiça Federal ou Comarca da Justiça Estadual cujo volume de ações judiciais justifique a criação de uma unidade administrativa especializada para o atendimento das decisões judiciais. Suas atribuições vêm atualmente dispostas na Portaria Conjunta PGF/INSS n. ${ }^{\circ}$ 83, de 04 de Junho de 2012, DOU de 06/06/2012.

${ }^{59}$ Por meio da Recomendação Conjunta CNJ e CJF n. ${ }^{\text {4 }}$ 4/2012, que dispõe sobre os elementos mínimos a serem inseridos nas sentenças ou atos ordinatórios exarados nos processos que versem sobre a concessão ou revisão de benefícios previdenciários ou assistenciais.

${ }^{60}$ No âmbito da $4^{\text {a }}$ Região, o TRF determina, com base no art. 461 do CPC, o cumprimento imediato dos acórdãos naquilo que se refere à obrigação de implementar benefício previdenciário. $\mathrm{O}$ entendimento, hoje já pacificado e aplicado inclusive no âmbito das Turmas Recursais, se firmou por ocasião do julgamento da Questão de Ordem na AC n. ${ }^{\circ}$ 2002.71.00.050349-7/RS, $3^{\text {a }}$ Seção, Rel. para o acórdão Des. Federal Celso Kipper, julgado em 09-08-2007. 


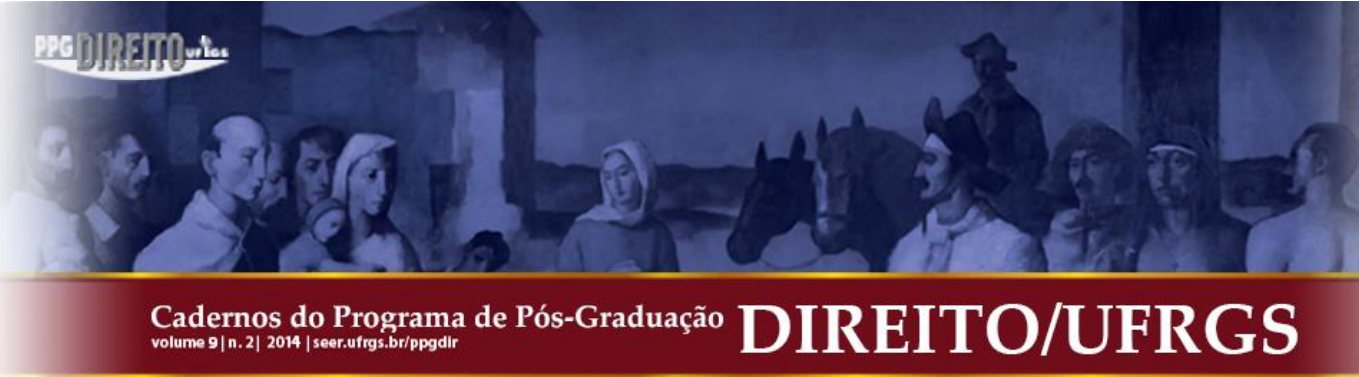

elaborar e apresentar os cálculos de liquidação. A execução invertida não serve para que se evite o ato formal de citação da autarquia nos termos do art. 730 do CPC, tampouco para que se deixe de atentar para o regime constitucional de pagamento de débitos pela Fazenda Pública; todavia, ela permite que as partes cheguem a um consenso quanto ao montante devido. O resultado é uma execução sem incidentes e que chega a seu termo, em razão do pagamento, com expressiva brevidade.

Ainda assim, não se pode perder de vista que, se as normas processuais buscam a plena satisfação do direito material, ou seja, se o que se pretende é um processo de resultados, ${ }^{61}$ há de se partir de uma correta configuração da controvérsia a ser dirimida e almejar, valendo-se de todos os mecanismos e técnicas processuais disponíveis, um resultado que, para além da prestação jurisdicional no caso concreto, reflita no aprimoramento da atuação do Estado na realização de direitos fundamentais sociais.

Consoante Carlos Alberto de Salles, a efetividade da tutela jurisdicional sobre dada matéria poderia ser analisada por meio de dois grupos de argumentos: argumentos de produção e argumentos de qualidade. Os argumentos de produção levam em conta qual mecanismo decisório produz um determinado resultado com menor dispêndio de recursos, incorporando, pois, preocupações de custo e duração do processo e apontando, enfim, para o objetivo de um processo mais rápido e mais barato. Por sua vez, os argumentos de qualidade traduzem os benefícios gerados por um determinado mecanismo processual, tendo em vista uma situação concreta. Como os argumentos de produção se afiguram insuficientes para verificação da adequação da tutela jurisdicional, a eles se somam os argumentos de qualidade, que levam em conta a superioridade dos variados resultados que um determinado mecanismo decisório produz:

A efetividade da tutela jurisdicional, portanto, há de ser aferida levando em conta,
também, outros elementos, como a capacidade do órgão jurisdicional em conhecer
corretamente os fatos apresentados, de mediar e conciliar posições conflitantes, de
perceber a verdadeira necessidade das partes e corresponder às suas expectativas
pessoais, de considerar todo o conjunto de argumentos aduzidos, de incentivar
condutas positivas das partes (em relação à instrução probatória e à execução do
julgado), e de considerar as repercussões finais da decisão produzida (em relação aos
sujeitos diretamente envolvidos e também à sociedade), entre outros fatores que

${ }^{61}$ CINTRA, Antonio Carlos de Araújo; GRINOVER, Ada Pellegrini; DINAMARCO, Candido Rangel. Teoria Geral do Processo. 29. ed. São Paulo: Malheiros, 2013. p. 34 e 192. 


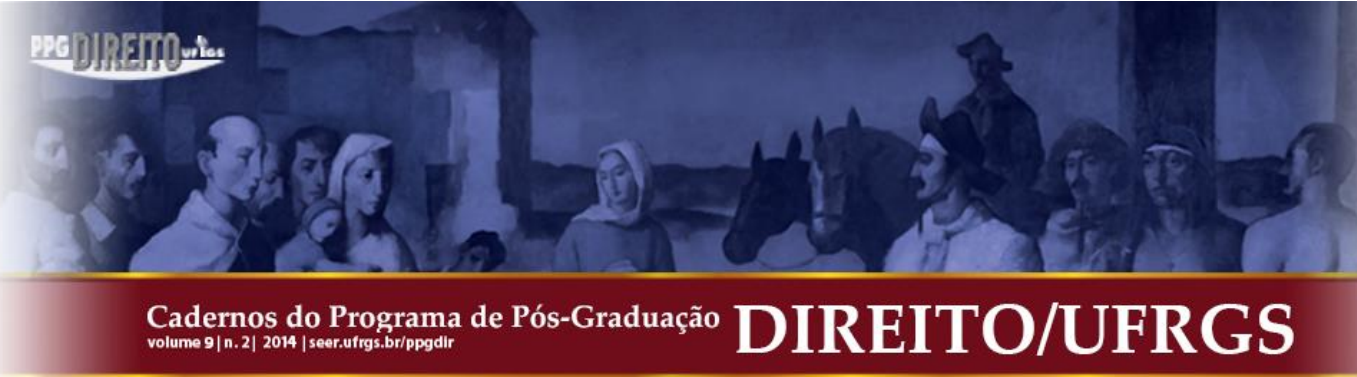
dimensionam a totalidade dos resultados a serem produzidos pela prestação
jurisdicional.

Numa consideração entre meios e fins, portanto, será efetivo o processo que atinge as finalidades a que se destina, considerando o conjunto de objetivos implícitos no direito material e a totalidade da repercussão da atividade jurisdicional sobre dada situação de fato. A efetividade da tutela jurisdicional, por conseguinte, impõe um juízo sobre a adequação do procedimento e do provimento jurisdicional em relação a uma determinada situação de fato.

Por esse viés, fundadas dúvidas surgem quanto à efetividade da prestação jurisdicional em matéria previdenciária. O conteúdo alimentar dessas demandas, especialmente quando se está diante da postulação de prestações substitutivas de renda, permite se afirme que há uma necessidade de maior celeridade não apenas por ocasião do cumprimento da decisão final, mas ao longo de toda a sua tramitação. De outra parte, as lides previdenciárias, por se enquadrarem no espectro do chamado processo de interesse público, constituem demandas individuais por meio das quais, ao fim e ao cabo, discutem-se conflitos políticos, ainda que de forma fragmentada, ${ }^{63}$ o que exige uma decisão final calcada em ampla análise dos fatos e profunda cognição dos argumentos trazidos pelas partes. $\mathrm{O}$ esperado equilíbrio entre as duas características da lide previdenciária, porém, não tem sido alcançado com observância do iter procedimental estabelecido pela lei processual.

A instrumentalidade do processo diz com a sua efetividade, e uma tutela jurisdicional efetiva exige a consideração do direito material subjacente. Nessa linha, seria possível falar-se em um verdadeiro direito processual previdenciário, identificado não pelos reflexos endoprocessuais afetos às prerrogativas do Estado-Administração em juízo, mas por um especial contexto de análise das regras processuais que disciplinam as demandas que versam sobre a matéria.

Independentemente da denominação, porém, o que se deseja com o reconhecimento de uma normatividade específica para o direito processual previdenciário é a realização do ideal constitucional de um processo justo, isto é, um processo conduzido por uma atuação

\footnotetext{
${ }^{62}$ SALLES, Carlos Alberto de. Processo civil de interesse público. In: SALLES, Carlos Alberto de (Org.). Processo Civil e Interesse Público: o processo como instrumento de defesa social. São Paulo: Revista dos Tribunais, 2003. p. 51.

${ }^{63}$ WATANABE, Kazuo. Processo civil de interesse público: introdução. In: SALLES, Carlos Alberto de (Org.). Processo Civil e Interesse Público: o processo como instrumento de defesa social. São Paulo: Revista dos Tribunais, 2003. p. 20.
} 


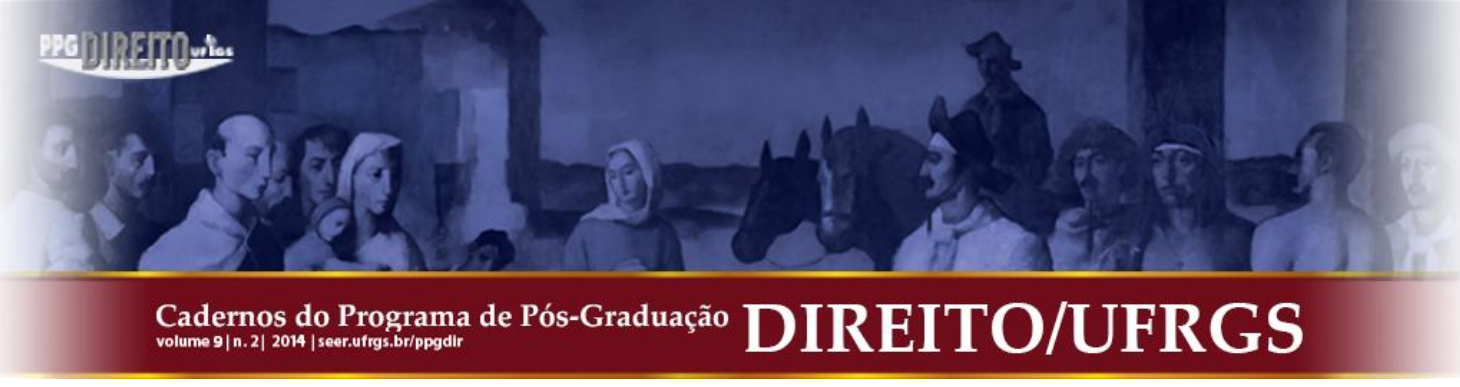

jurisdicional que leve em conta os particularismos dessa lide. ${ }^{64} \mathrm{Na}$ correta afirmação de Tavares,

\begin{abstract}
O direito processual previdenciário deve proporcionar subsídios para a prolação de uma decisão que pacifique a questão relativa à fruição de um direito social fundamental e que tenha compromisso com o seguro, a fim de proteger adequadamente os beneficiários, sem onerar o grupo e a sociedade de maneira indevida. ${ }^{65}$
\end{abstract}

$\mathrm{Na}$ busca do processo como instrumento para atender a esses escopos, o Projeto de Novo Código de Processo Civil, ao corrigir algumas distorções da legislação processual existente e trazer alternativas afetas ao modo de ser do processo ${ }^{66}$, pode lançar bases para um processo judicial mais efetivo em matéria previdenciária. É o que se espera, por exemplo, dos dispositivos que incentivam a figura do juiz participativo, ou seja, aquele que se importa com o esclarecimento das partes, que contorna vícios processuais que ensejem involução na marcha procedimental e, especialmente, que delimita o quadro controvertido, sinalizando os ônus probatórios e envidando esforços na busca por elementos probatórios importantes, imprimindo, enfim, a marca do diálogo no processo. Pretende-se, assim, "abandonar o método de condução meramente formal do processo, que limita o impulso oficial à intimação dos litigantes para que postulem e à rejeição ou deferimento impensados das provas protestadas."

Na mesma toada, a previsão expressa de produção antecipada da prova para permitir a conciliação entre as partes e a possibilidade de intimação pessoal da parte interessada relativamente a proposta de acordo formulada nos próprios autos pela parte contrária, por certo, virão para estimular a conciliação nas demandas previdenciárias, e a observância dos precedentes poderão servir para amenizar a dispersa jurisprudência previdenciária hoje existente.

A relevância dos valores constitucionais contrapostos na demanda previdenciária exige uma tutela jurisdicional efetiva, a qual deve derivar de um processo rápido e, ao mesmo tempo, capaz de eliminar o conflito. Entende-se, aqui, que esse objetivo somente será

\footnotetext{
${ }^{64}$ SAVARIS, p. 54.

${ }^{65}$ TAVARES, Marcelo Leonardo. Direito Previdenciário. 12. ed. Niterói: Impetus, 2010. p. 33-38.

${ }^{66}$ Está-se, afinal, na terceira onda renovatória, traduzida em múltiplas tentativas à vista de fins diversos, tais como simplificação e racionalização de procedimentos, conciliação, justiça participativa etc. CINTRA, Antonio Carlos de Araújo; GRINOVER, Ada Pellegrini; DINAMARCO, Candido Rangel. Teoria Geral do Processo. 29. ed. São Paulo: Malheiros, 2013. p. 34 e 52.

${ }^{67}$ SILVEIRA, João José Custódio da. O juiz e a condução equilibrada do processo. São Paulo: Saraiva, 2012. p. 157.
} 


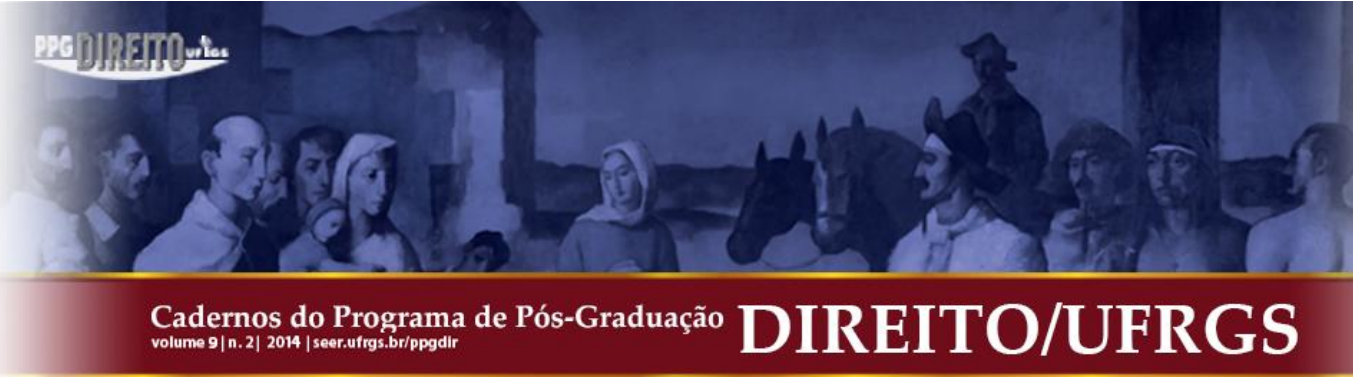

alcançado por meio de um procedimento menos rígido, menos formal e mais vinculado ao direito material, no qual haja plena atuação das partes, atentando para seus deveres de boa-fé e lealdade, mas também com forte atuação direcionadora do juízo, garantindo uma marcha processual mais célere e mais enxuta no intuito de uma solução que, equacionando cidadão e Administração, entregue a tutela jurisdicional a quem tiver razão, afinal, este é "ao mesmo tempo um princípio-síntese e um objetivo final, no universo dos princípios e garantias inerentes ao direito processual constitucional." 68

\section{CONSIDERAÇÕES FINAIS}

Para a crescente litigiosidade previdenciária concorrem, de forma simultânea, uma série de fatores. Alguns deles, por seu caráter socioeconômico, dizem diretamente com a maior ou menor ocorrência de alguma das contingências sociais para as quais foi pensada a própria política de proteção previdenciária no Brasil. Outros relacionam-se à postura ou à atuação que os envolvidos no conflito previdenciário exercem em nível extraprocessual. É no âmbito desses últimos que se pode refletir sobre as possibilidades de uma influência positiva não apenas para a pacificação do conflito em sede processual, mas para sua própria prevenção.

No que toca à Administração Pública, talvez os efeitos das reformas gerenciais implementadas nas últimas décadas ainda demorem a aparecer. Ainda assim, deve ser constante a preocupação em expandir e qualificar a prestação de seus serviços, seja pelo viés da garantia dos direitos processuais do cidadão na análise administrativa de sua pretensão, seja por meio de uma política voltada também para a conscientização e o esclarecimento da sociedade civil quanto aos seus direitos sociais previdenciários.

Ao Poder Judiciário, por sua vez, incumbe a tarefa de repensar sua precípua função em face da lide previdenciária. Resumi-la à mera substituição da atividade-fim da Administração, além de sobrecarregar a máquina judiciária, implica apequenar a mais relevante de suas atribuições: o exercício do controle externo sobre os demais poderes da República. Entende-se que é somente por esse prisma que o Poder Judiciário atuará ativamente para o aperfeiçoamento da gestão da política pública previdenciária, com o que ganhará não apenas o

${ }^{68}$ DINAMARCO, Cândido Rangel. Nova era do processo civil. São Paulo: Malheiros, 2003. p. 12-13. 


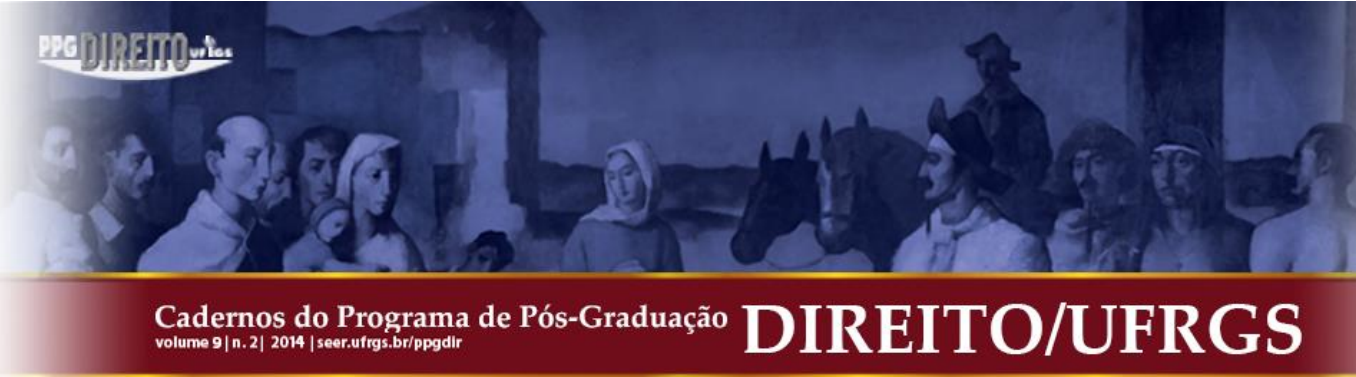

indivíduo em sua demanda individual, mas todos os cidadãos albergados pelo Regime Geral da Previdência Social.

A par disso, resta, ainda, a necessidade de se pensar em alternativas que garantam às demandas previdenciárias uma efetiva tutela jurisdicional. Daí a importância de, atentando para as especificidades do direito material subjacente à lide, repensar e reinterpretar as normas processuais postas e lançar mão de outros instrumentos ou técnicas que simplifiquem o procedimento e contribuam para que haja uma atuação colaborativa e um verdadeiro diálogo entre as partes, aprimorando, assim, o processo judicial previdenciário enquanto instrumento para a composição dos conflitos previdenciários. Nesse sentido, o advento de um pretendido direito processual previdenciário poderia traduzir a constante necessidade de, no âmbito do processo judicial respectivo, equacionar a pretensão de fruição de um direito social fundamental com as decisões políticas que precedem sua concretização.

\section{REFERÊNCIAS}

AMARAL, Gustavo. Direito, escassez e escolha: critérios jurídicos para lidar com a escassez de recursos e as decisões trágicas. 2. ed. Rio de Janeiro: Lúmen Juris, 2010.

BRASIL. Congresso Nacional. Senado Federal. Comissão de Juristas Responsável pela Elaboração de Anteprojeto de Código de Processo Civil. Brasília: Senado Federal, Presidência, 2010.

Conselho Nacional de Justiça. Universidade Federal do Rio Grande do Sul. As interrelações entre o processo administrativo e o judicial (em matéria fiscal), a partir da identificação de contenciosos cuja solução deveria ser tentada previamente na esfera administrativa. Relatório Final. Porto Alegre, 2011. Disponível em: <http://www.cnj.jus.br/images/pesquisas-judiciarias/Publicacoes/relat_pesquisa_ ufrgs_edital1_2009.pdf.> Acesso em: 31 ago. 2013.

Conselho Nacional de Justiça. Fundação Getúlio Vargas. Diagnóstico sobre as causas de aumento das demandas judiciais cíveis, mapeamento das demandas repetitivas e propositura de soluções pré-processuais, processuais e gerenciais à morosidade da Justiça. Disponível em: <http://www.cnj.jus.br/images/pesquisas-judiciarias/Publicacoes/ relat_pesquisa_fgv_edital1_2009.pdf>. Acesso em: 13 set. 2013. 


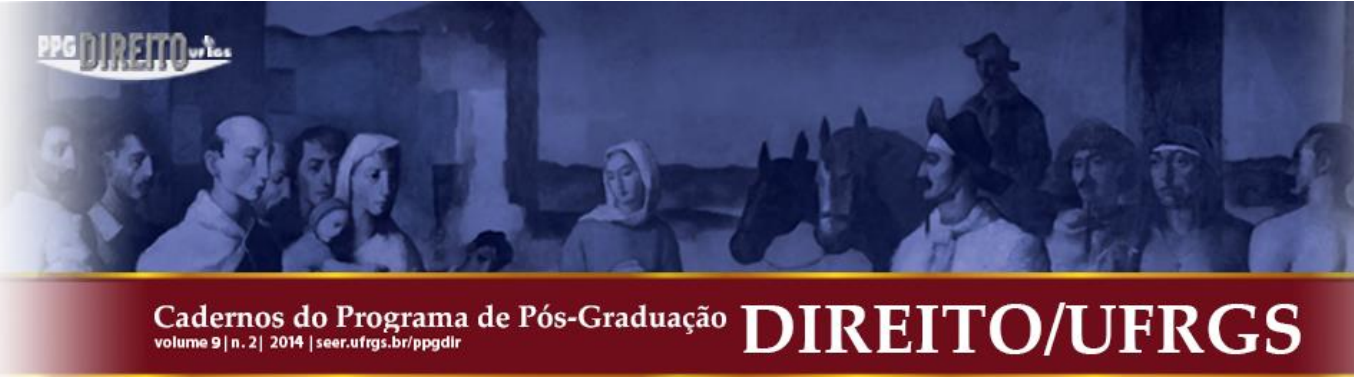

. Conselho Nacional de Justiça. 100 maiores litigantes. Brasília, 2012. Disponível em:<http://www.cnj.jus.br/images/pesquisas-judiciarias/Publicacoes/100_

maiores_litigantes.pdf $>$. Acesso em: 02 set. 2013.

Ministério da Previdência Social. Secretaria de Políticas de Previdência Social. Projeções atuariais para o Regime Geral de Previdência Social. Brasília, março de 2012. Disponível em: <http://www.planejamento.gov.br/secretarias/ upload/Arquivos/sof/orcamento_13/Anexo_IV.5_RGPS.pdf>. Acesso em: $30 \mathrm{dez} .2013$.

Ministério da Previdência Social. Secretaria de Políticas e Previdência Social. Resultado do Regime Geral de Previdencia Social - RGPS. Brasília, dezembro de 2013. Disponível em: <http://www.previdencia.gov.br/politicas-de-previdencia-social-rgps/>. Acesso em: 20 dez. 2013.

BUENO, Cassio Scarpinella. A emergência do direito processual público. In: SUNDFELD, Carlos Ari e BUENO, Cassio Scarpinella (Org.). Direito processual público: a Fazenda Pública em Juízo. São Paulo: Malheiros, 2000.

Inafastabilidade do controle judicial da Administração. In: SUNDFELD, Carlos Ari e BUENO, Cassio Scarpinella (Org.). Direito processual público: a Fazenda Pública em Juízo. São Paulo: Malheiros, 2000.

Processo Civil de interesse público: uma proposta de sistematização. In: SALLES, Carlos Alberto de (Org.). Processo Civil e Interesse Público: o processo como instrumento de defesa social. São Paulo: Revista dos Tribunais, 2003.

. Curso sistematizado de direito processual civil. v. 1. 8. ed. São Paulo: Saraiva, 2014.

CAIRO JR., José. Curso de Direito do Trabalho. 2. ed. Salvador: JusPodium, 2008.

CANOTILHO, José Joaquim Gomes. Constituição Dirigente e Vinculação do Legislador. 2. Ed. Coimbra: Coimbra, 2001.

CINTRA, Antonio Carlos de Araújo; GRINOVER, Ada Pellegrini; DINAMARCO, Candido Rangel. Teoria Geral do Processo. 29. ed. São Paulo: Malheiros, 2013. 


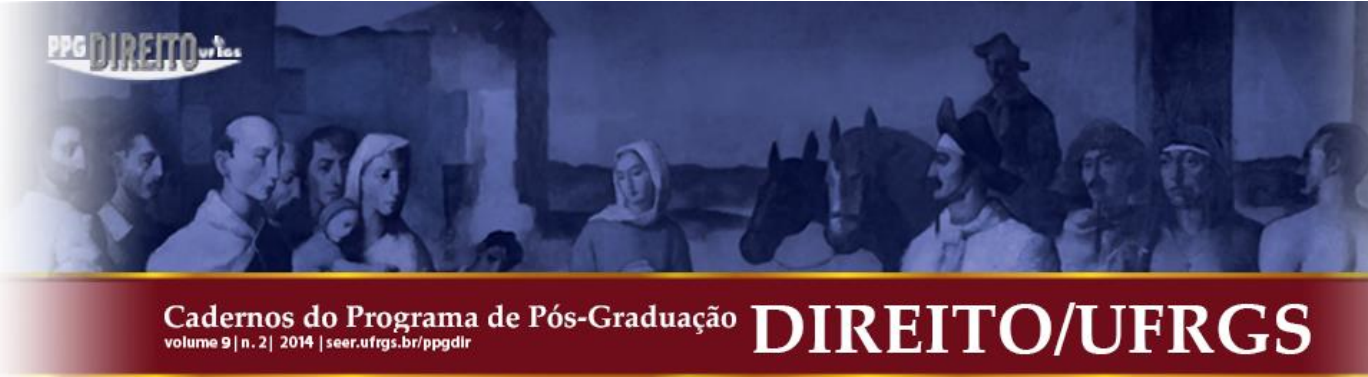

CRUZ E ALVES, Adler Anaximandro de. A atuação cidadã da AGU na redução da litigiosidade envolvendo o Instituto Nacional do Seguro Social: considerações acerca dos instrumentos de ação da AGU capazes de promover o amplo reconhecimento de direitos sociais. Revista da $A G U$, ano 9, n. ${ }^{\circ}$ 23, Brasília, jan.-mar. 2010, p. 9-46.

CUNHA, Leonardo José Carneiro da. A Fazenda Pública em Juízo. 5. ed. São Paulo: Dialética, 2007.

DIAS, Andréia Castro. A alta programada e os benefícios por incapacidade. In: VAZ, Paulo Afonso Brum e SAVARIS, José Antonio (Org.). Curso modular de direito previdenciário. v. 2. Florianópolis: Conceito, 2010. p. 391-432.

DIDIER JR., Fredie; BRAGA, Paula Sarno e OLIVEIRA, Rafael. Curso de Direito Processual Civil. v. 2. Salvador: JusPodium, 2007.

DINAMARCO, Cândido Rangel. A Instrumentalidade do Processo. São Paulo: Malheiros, 2003.

Nova era do processo civil. São Paulo: Malheiros, 2003.

Instituições de Direito Processual Civil. 7. ed. São Paulo: Malheiros, 2013.

FERREIRA FILHO, Manoel Gonçalves. Curso de Direito Constitucional. 35. ed. São Paulo: Saraiva, 2009.

JUSTEN FILHO, Marçal. Curso de Direito Administrativo. São Paulo: Saraiva, 2005.

KRELL, Andreas J. Controle judicial dos serviços públicos básicos na base dos direitos fundamentais sociais. In: SARLET, Ingo Wolfgang (Org.). A Constituição concretizada: construindo pontes com o público e o privado. Porto Alegre: Livraria do Advogado, 2000.

LEAL, Rosemiro Pereira. Teoria Geral do Processo: primeiros estudos. São Paulo: Síntese, 1999.

MARTINS, Sergio Pinto. Direito Processual do Trabalho. 20. ed. São Paulo: Atlas, 2003. 


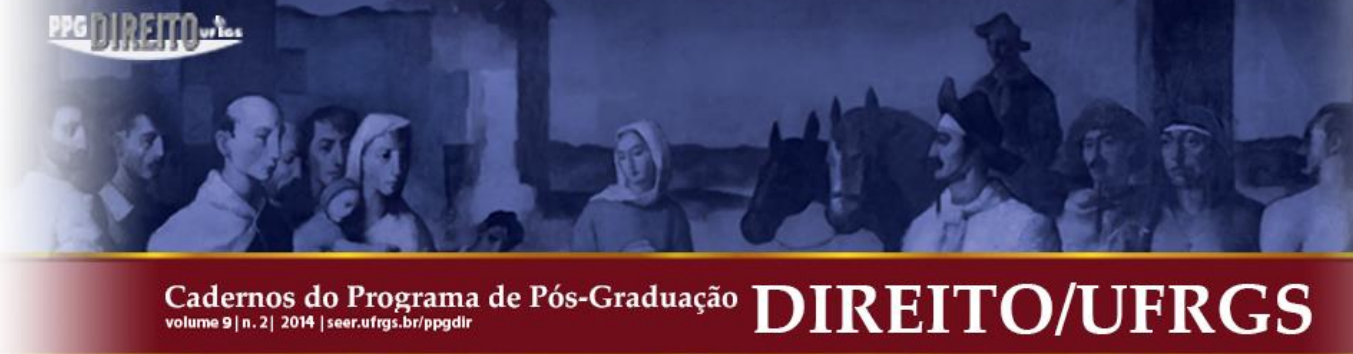

SAVARIS, José Antonio. Algumas reflexões sobre a prova material previdenciária. In: Instituto Brasileiro de Direito Previdenciário (Coord.). Direito Previdenciário em debate. Curitiba: Juruá, 2008.

Direito Processual Previdenciário. 2. ed. Curitiba: Juruá, 2010.

SILVA, Fábio de Souza. O princípio do contraditório e a suspensão de benefício previdenciário. Revista da Associação dos Juízes Federais do Brasil, ano 23, n. o 90, jul.-nov. 2008. p. 135-148.

SILVA, Jaqueline Mielke e XAVIER, José Tadeu Neves. Reforma do Processo Civil. Porto Alegre: Verbo Jurídico, 2006.

SILVEIRA, João José Custódio da. O juiz e a condução equilibrada do processo. São Paulo: Saraiva, 2012.

TAVARES, Marcelo Leonardo. Direito Previdenciário. 12. ed. Niterói: Impetus, 2010.

TORRES, Marcelo Douglas de Figueiredo. Estado, democracia e administração pública no Brasil. Rio de Janeiro: FGV, 2004.

TSUTIYA, Augusto Massayuri. Curso de Direito da Seguridade Social. São Paulo: Saraiva, 2007.

VIANA, João Ernesto Aragonés. Curso de Direito Previdenciário. 4. ed. São Paulo: Atlas, 2011.

WATANABE, Kazuo. Processo civil de interesse público: introdução. In: SALLES, Carlos Alberto de (Org.). Processo Civil e Interesse Público: o processo como instrumento de defesa social. São Paulo: Revista dos Tribunais, 2003.

ZYMLER, Benjamin. Direito administrativo e controle. Belo Horizonte: Fórum, 2006. 


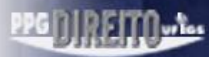

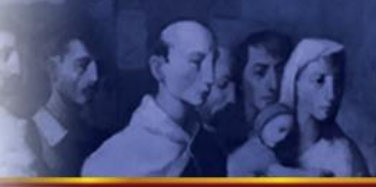

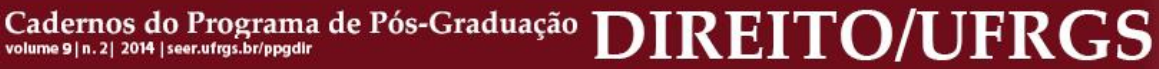

33 